Geosci. Model Dev. Discuss., doi:10.5194/gmd-2016-168, 2016

Manuscript under review for journal Geosci. Model Dev.

Published: 29 September 2016

(c) Author(s) 2016. CC-BY 3.0 License.

\title{
The downscaling and adjustment method ADAMONT v1.0 for climate projections in mountainous regions applicable to energy balance land surface models
}

\author{
Deborah Verfaillie ${ }^{1}$, Michel Déqué ${ }^{1}$, Samuel Morin ${ }^{1}$, and Matthieu Lafaysse ${ }^{1}$ \\ ${ }^{1}$ CNRM UMR 3589, Météo-France/CNRS, Toulouse, France \\ Correspondence to: Deborah Verfaillie (deborah.verfaillie@meteo.fr)
}

\begin{abstract}
.
We introduce a method - called ADAMONT (ADAptation of RCM outputs to MOuNTain regions) v1.0 - to downscale and adjust daily climate projections from a regional climate model against a regional reanalysis of hourly meteorological conditions using quantile mapping. The method proces adjusted hourly time series of temperature, precipitation, wind speed, humidity, and short- and longwave radiation, which can in turn be used to force any energy balance land surface model. The ADAMONT method is evaluated through its application to the ALADIN-Climate v5 RCM forced by the ERA-Interim reanalysis, compared to the SAFRAN reanalysis, used as the pseudo-observation database covering the entire French Alps split into 23 massifs within which meteorological conditions are provided for several elevation bands separated by $300 \mathrm{~m}$ altitude. Different evaluation criteria are analysed for temperature, precipitation, but also snow depth, which is computed by the SURFEX/ISBA-Crocus model using the meteorological driving data generated using this method. The impact of the learning period and of the method used to select neighbouring RCM grid points for each SAFRAN massif/altitude configuration is tested. The performance of the method is satisfying, with similar or even better evaluation metrics than previous literature findings. Results for temperature are generally better than for precipitation. Snow depth yields good results, which can be viewed as indicating a reasonably good inter-variable consistency of the meteorological data produced by the method. The temporal transferability of the method is assessed through the comparison of results obtained using different learning periods, and shows that the method is sensitive to the period considered due to the empirical treatment of values beyond the $99.5^{\text {th }}$ quantile. The use of a complex RCM grid points selection technique taking into account horizontal but also altitudinal proximity to SAFRAN massif centroids/altitude couples generally degrades evaluation metrics for high altitudes, compared to a simpler 2-dimensional proximity selection technique.
\end{abstract}


Geosci. Model Dev. Discuss., doi:10.5194/gmd-2016-168, 2016

Manuscript under review for journal Geosci. Model Dev.

Published: 29 September 2016

(c) Author(s) 2016. CC-BY 3.0 License.

\section{Introduction} of climate change has been gradually accepted and societies and governments have started to plan upcoming mitigation and adaptation policies (IPCC, 2013, 2014a, b, c). For a given socio-economic or greenhouse-gas concentration scenario, these projections generally concern future temperature and precipitation, and associated extreme events, and are usually achieved using the outputs of general circulation models (GCMs) downscaled using statistical or dynamical methods (e.g. Giorgi and Mearns, 1991; Fowler et al., 2007; Themeß1 et al., 2012). In mountain regions such as the Alps, where a large fraction of the income comes from winter tourism (about 20\% of the French tourism income in 2011, DSF, 2011) and water and hydro-power production, particular attention is brought to current and future snow availability (e.g. Martin et al., 1994; Beniston, 1997; Castebrunet et al., 2014; Piazza et al., 2014; Schmucki et al., 2014). The question of the associated changes in river discharges (Lafaysse et al., 2014), their consequences on water storage management (François et al., 2015), the future vulnerability of alpine ecosystems (Boulangeat et al., 2014; Thuiller et al., 2014) as well as the future occurrence of climate-related hazards such as debris flows (Jomelli et al., 2009) and avalanches (Castebrunet et al., 2014) is also under consideration. In order to generate projections of olutions typically between 10 and $50 \mathrm{~km}$, driven by GCMs in a dynamical downscaling approach is not sufficient to capture the fine-scale processes and thresholds at play. Indeed, the altitudinal resolution matters, since the precipitation phase is mainly controlled by the temperature which is altitude-dependent. Several mountain socio-economic activities, such as ski resorts operations, critically depend on the altitude of the rain/snow transition. Furthermore, in addition to their lack of representation of the entire altitude range of mountainous areas, simulations from GCMs and RCMs suffer from biases compared to local observations (Christensen et al., 2008; Rauscher et al., 2010; Kotlarski et al., 2014). Raw climate projections must therefore be adjusted and further downscaled (Déqué, 2007; Themeß1 et al., 2011; Gobiet et al., 2015), before they can be used as such (time series of temperature, precipitation, ...), or in order to force specific impact models.

Various downscaling and bias adjustment methods have been developed (Maraun et al., 2010; Teutschbein and Seibert, 2012, 2013). They are generally separated into two categories depending on the approach used, but they all require an observation dataset which (i) meets the data requirements of the impact model and (ii) is sufficiently long and reliable to be used to infer the relationships between the observations and the raw climate projections during the observation time period. Perfect prognosis approaches search for relationships between observed large-scale predictors (generally from reanalyses) and observed local-scale predictands. The analog (Dayon et al., 2015) and the weather typing (Vrac et al., 2007a) methods fall into this category. In contrast, model output statistics approaches calibrate model outputs against observations. Different methods of variable complexity belong to this category, such as scaling methods (linear scaling, local intensity scaling, variance scal- 
Geosci. Model Dev. Discuss., doi:10.5194/gmd-2016-168, 2016

Manuscript under review for journal Geosci. Model Dev.

Published: 29 September 2016

(c) Author(s) 2016. CC-BY 3.0 License.

ing, ...), delta-change methods (e.g. Abegg et al. (2007); Hantel and Hirtl-Wielke (2007); Schmucki et al. (2014)) and distribution mapping methods (e.g. Boé et al. (2007); Déqué (2007); Gobiet et al. (2015); Olsson et al. (2015)). The latter include quantile mapping, which is considered as an efficient and easy to implement adjustment method (Themeß1 et al., 2011; Teutschbein and Seibert, 2012; Maurer and Pierce, 2014; Gobiet et al., 2015). The main advantage of this method is that it adjusts deviations in the shape of the distribution, and is thus able to adjust deviations not only for the mean but the variability (Themeß1 et al., 2011). Moreover, the adjustment is not strictly restricted to the range of observed values in the reference period, which is the case for example for methods based on analog weather patterns (e.g. Déqué, 2007; Themeß1 et al., 2011; Rousselot et al., 2012; Dayon

70 et al., 2015). It can thus be used for evaluation of climate extremes or projections at the end of the $21^{\text {st }}$ century, as long as the probability associated to these events is robustly estimated from a long enough sample. The main limits of quantile mapping are the assumption of time-invariant model biases on which it is based (which is an assumption common to most bias adjustment methods), and the fact that temporal properties of the model are not adjusted, i.e. if the model has a chronological behaviour which differs from the observations (too chaotic or too persistent), this will not be adjusted (Déqué, 2007). Moreover, quantile mapping does not guarantee spatial and inter-variables consistency, which is the case for the analog method for example.

The choice of the downscaling and adjustment method implemented depends on the application and on the availability of raw climate projections and appropriate observation datasets. Raw regional climate projection data are increasingly made available to a broad scientific community, e.g. the World Climate Research Program (WCRP) Coordinated Regional Downscaling Experiment (CORDEX, Giorgi et al. (2009)), which aim is to improve and distribute regional climate modelling worldwide. Its European branch, EURO-CORDEX (Jacob et al., 2014), gathers regional climate simulations over Europe from 30 different modelling groups at $50 \mathrm{~km}$ (EUR-44) and $12.5 \mathrm{~km}$ (EUR-11) resolution. On the observation side, the use of surface meteorological reanalysis is a powerful alternative to station observation data to provide the necessary observational dataset (Berg et al., 2015). Indeed, the process by which such reanalyses are generated address the time and space variations of the meteorological conditions, and by design they consist of gap-free and complete time series. In mountainous regions, snow on the ground plays a pivotal role, but the snowpack response to meteorological conditions depends on intertwined processes, involving surface mass and energy balance as well as internal processes (e.g. Martin et al., 1994). Not only temperature and precipitation act on the snowpack, but a broader range of meteorological conditions and their diurnal variations. As a consequence, considering only downscaled and adjusted daily temperature and precipitation would miss some of the non-linear response of the snowpack. The SAFRAN meteorological analysis has been developed specifically to address the needs of snowpack numerical simulations, and contains hourly time series of temperature, precipitation, wind speed, humidity, and short- and longwave radiation for so-called massifs (ranging between 500 and $2000 \mathrm{~km}^{2}$ in the French Alps) by elevation 
Geosci. Model Dev. Discuss., doi:10.5194/gmd-2016-168, 2016

Manuscript under review for journal Geosci. Model Dev.

Published: 29 September 2016

(c) Author(s) 2016. CC-BY 3.0 License.

steps of $300 \mathrm{~m}$ (Durand et al., 2009a, b). Combining the strength and efficiency of the quantile mapping downscaling and adjustment methods using the SAFRAN reanalysis as a pseudo-observation dataset in order to drive energy balance snowpack and land surface models is a highly desirable goal making full use of the current capabilities of climate impact assessment tools for mountainous regions. In addition, the use of such methods ensures that the chronology of the adjusted and downscaled climate projections will match the chronology of the RCM, which may be affected by climate change through variations of the seasonality of meteorological conditions. Such impacts cannot be addressed using delta-change methods, which by definition apply fixed changes to an observed time series conserving its statistical persistence properties and seasonality (e.g. Abegg et al., 2007; Hantel and Hirtl-Wielke, 2007; Schmucki et al., 2014) although this could evolve significantly under changed climate conditions.

In this study we introduce a method - the ADAMONT (ADAptation of RCM outputs to MOuN-

Tain regions) v1.0 method - to downscale and adjust biases in climate model projections in order to provide hourly adjusted temperature, precipitation, wind speed, humidity, and short- and longwave radiation for recent and future time series. Quantile mapping is applied for all these variables using daily outputs from a RCM, which are downscaled and statistically adjusted against the SAFRAN reanalysis (Durand et al., 2009b), an extensive reanalysis of these various meteorological variables which operates at the massif scale by $300 \mathrm{~m}$ elevation bands. These adjusted fields are then used to force the SURFEX/ISBA-Crocus (Vionnet et al., 2012) model over the French Alps. In order to evaluate the performance of the ADAMONT method, here we apply this method to the ALADINClimate v5 RCM (Colin et al., 2010) forced by the ERA-Interim reanalysis (Dee et al., 2011). Sect. 2 focuses on the models used and the evaluation of the ADAMONT method. The performance of the method is then presented and discussed in Sect. 3, and general conclusions are drawn in Sect. 5.

\section{Models and methods}

\subsection{RCM simulation}

In this study, our downscaling and adjustment method is applied to the Météo France RCM ALADIN. This RCM, forced by the ERA-Interim reanalysis, was run daily at $12.5 \mathrm{~km}$ resolution. This reference simulation was then downscaled and adjusted against the SAFRAN reanalysis (Sect. 2.2) using the method described in Sect. 2.4. We chose to work on a spatial domain smaller than the one used in EURO-CORDEX (domain covering all of Europe), in order to evaluate the method and not the output of the RCM itself. Indeed, the smaller the domain, the more it is constrained (Alexandru et al., 2007). Simulations carried out over a domain centered on France, called FRB12 (Fig. 1) were thus evaluated (Sect. 2.5). 
Geosci. Model Dev. Discuss., doi:10.5194/gmd-2016-168, 2016

Manuscript under review for journal Geosci. Model Dev.

Published: 29 September 2016

(c) Author(s) 2016. CC-BY 3.0 License.

\subsection{SAFRAN reanalysis}

The SAFRAN system is a meteorological downscaling and surface analysis system (Durand et al., 1993), which provides hourly data of temperature, precipitation amount and phase, specific humidity, wind speed, and shortwave and longwave radiation for each mountain region (called massif) in the French Alps (23 massifs, as illustrated in Fig. 1). Massifs (Durand et al., 1993, 1999) correspond to regions ranging approximately between 500 and $2000 \mathrm{~km}^{2}$ for which meteorological conditions are assumed to be spatially homogeneous but vary with altitude. SAFRAN data are available for elevation bands with a resolution of $300 \mathrm{~m}$. SAFRAN was used by Durand et al. (2009b) to create a meteorological reanalysis over the French Alps by combining the ERA-40 reanalysis (Uppala et al., 2005 ) with various meteorological observations including in situ mountain stations, radiosondes and satellite data. It was complemented after the end of the ERA-40 reanalysis (2002) by large-scale meteorological fields from the ARPEGE analysis, so that it now spans the period from 1959 to 2015 , making it one of the longest meteorological reanalyses available in the French mountain regions.

\subsection{SURFEX/ISBA-Crocus model}

145 Crocus (Brun et al., 1989, 1992) is a detailed snowpack model which has been used operationally for French avalanche forecasting for more than 20 years. It has been recently integrated in the SURFEX externalised surface module (Masson et al., 2013), which contains the land surface scheme ISBA (Interactions between Soil, Biosphere, and Atmosphere). The new SURFEX/ISBA-Crocus model (Vionnet et al., 2012) enables the computation of the exchanges of energy and mass between the snow surface and the atmosphere (radiative balance, turbulent heat and moisture fluxes, ...), but also between the snowpack and the ground underneath. The one-dimensional multilayer physical snow scheme Crocus is able to simulate the evolution of the snowpack over time, by accounting for several processes occurring in the snowpack, such as thermal diffusion, phase changes, metamorphism, etc. A detailed description of the processes taken into account and the variables of the Crocus scheme can be found in Brun et al. (1989, 1992) and Vionnet et al. (2012). The SAFRAN-Crocus model chain has been operationally used for more than 20 years for avalanche hazard forecasting and extensively evaluated over the alpine domain in particular against snow depth observation stations (Durand et al., 1999, 2009b; Lafaysse et al., 2013).

\subsection{Description of the ADAMONT method}

RCM outputs fed by GCMs suffer from systematic deviations compared to local observations, which are partly due to the model configuration and boundary conditions provided by the GCM, but are also linked to their insufficient spatial and altitudinal resolution (Déqué and Somot, 2008; Kotlarski et al., 2012, 2014). The spatial and altitudinal differences between the ARPEGE/ALADIN simulations compared to the SAFRAN reanalysis are illustrated in Fig. 1. It can clearly be seen that the model 
Geosci. Model Dev. Discuss., doi:10.5194/gmd-2016-168, 2016

Manuscript under review for journal Geosci. Model Dev.

Published: 29 September 2016

(c) Author(s) 2016. CC-BY 3.0 License.

grid points closest to the SAFRAN massifs centroids are not located directly above the centroids (potential spatial bias), but more importantly, have a surface elevation which can differ significantly from the different altitudes found in each massif (potential altitudinal bias). To mitigate such biases compared to observations, bias adjustment methods are often used before running specific models such as energy balance land surface models.

The adjustment method used in this study is the quantile mapping method (Déqué, 2007; Gobiet et al., 2015). This method, which is considered one of the most efficient bias adjustment methods available (Themeß1 et al., 2011; Maurer and Pierce, 2014; Gobiet et al., 2015) is relatively easy to implement. It consists in plotting the quantiles of the simulated historical distribution against the quantiles of the observed distribution (quantile-quantile plot), and using the resulting mapping function to adjust the distribution of model projections. Because the spatial resolution of the adjusted RCM is close to the resolution of the observations (SAFRAN massifs), there is no risk of introducing any artificial inflation of the simulated series, and therefore quantile mapping is adapted (Maraun, 2013). As mentioned above, no bias-adjustment method is perfect, and quantile mapping suffers from some disadvantages, namely the assumption of time-invariant model biases, the fact that temporal properties of the model are not corrected for and the fact that the spatial and inter-variables consistency is not guaranteed. Driouech et al. (2009) showed that for zonal climates, such as the one of Morocco, quantile mapping adjustment can vary for different weather regimes. Similarly, Addor et al. (2016) demonstrated the sensitivity of quantile mapping adjustment to circulation biases over the Alpine domain. To limit the dependence of our method to climate, weather regimes are thus taken into account in our method.

The downscaling and adjustment method developed in this study consists in the following steps:

1. The RCM grid points closest (in terms of horizontal distance) to the SAFRAN massifs centroids are selected, and the surface data (temperature, total precipitation, wind speed, specific humidity and incoming short- and longwave radiation) of each selected grid point are applied directly to the different elevations of the corresponding SAFRAN massif. An alternative was tested, where the RCM grid points closest to the SAFRAN massifs centroids in terms of horizontal AND vertical distances are selected, by minimizing the distance :

$\sqrt{(\Delta x)^{2}+(\Delta y)^{2}+(N \times \Delta z)^{2}}$,

where $\Delta x, \Delta y$ and $\Delta z$ represent the longitudinal, latitudinal and vertical distances (in $\mathrm{km}$ ) between SAFRAN massifs centroids and the RCM grid points, and $N$ is referred to as the elevation factor. The latter was introduced to take into account the strong dependence of meteorological variables (mainly precipitation and temperature) on altitude (e.g. Gottardi et al., 2012; Kotlarski et al., 2012).

2. Four different daily weather regimes were diagnosed from ERA-Interim, based on the geopotential height at $500 \mathrm{hPa}$, following Michelangeli et al. (1995). 
Geosci. Model Dev. Discuss., doi:10.5194/gmd-2016-168, 2016

Manuscript under review for journal Geosci. Model Dev.

Published: 29 September 2016

(c) Author(s) 2016. CC-BY 3.0 License.

3. SAFRAN data are integrated from hourly to daily to match the data content of the available RCM output. The integration method depends on the variable considered (see Table 1).

4. Percentiles of the RCM distribution and the SAFRAN distribution are then calculated at each point, for each variable, each season (DJF, MAM, JJA, SON) and each weather regime. Each snow year is considered from the $1^{\text {st }}$ of August to the $31^{\text {st }}$ of July of the following year.

5. Quantile mapping is then applied to the entire RCM dataset for the period 1980-2010, taking into account the season and the weather regime.

6. For each day in the RCM dataset, an analogous date is chosen in the SAFRAN dataset, matching the following criteria: the month and the regime must be the same as in the RCM dataset, mean precipitation over the Alps must be consistent between datasets (i.e. if there is no precipitation in the RCM, precipitation in the SAFRAN analogue must be zero), and whenever possible, consecutive time slices are chosen in the SAFRAN dataset in order to avoid artificial jumps in the final data linked to the choice of analogues.

7. The adjusted RCM dataset is then disaggregated from a daily integration period into an hourly time step, by using the hourly SAFRAN data from each analogous date chosen in the previous step to reconstruct the daily cycle of the data. Different disaggregation criteria (mean daily value, maximum and minimum values, value of the last time step, smallest possible jump between consecutive days, ...) are chosen depending on the variable considered (Table 1). For the disaggregation of ALADIN adjusted temperature from daily to hourly (Table 1), a compromise must be made between obtaining minimum and maximum daily values as close as possible to ALADIN adjusted daily minimum and maximum and minimizing the possible jump in adjusted values between consecutive days. This is achieved by minimising the function:

$$
\begin{array}{r}
Q(\alpha)=\left[T_{A L}^{h}(1 h, i)-T_{A L}^{h}(24 h, i-1)\right]^{2}+\alpha\left[\operatorname{Tmin}_{A L}^{h}(i)-\operatorname{Tmin}_{A L}^{d, a d j}(i)\right]^{2} \\
+\alpha\left[\operatorname{Tmax}_{A L}^{h}(i)-\operatorname{Tmax}_{A L}^{d, a d j}(i)\right]^{2}
\end{array}
$$

where $T_{A L}^{h}(1 h, i)$ and $T_{A L}^{h}(24 h, i-1)$ are the hourly adjusted ALADIN temperature values at the first time step of day i and at the last time step of day i-1, $\operatorname{Tmin}_{A L}^{h}(i)$ and $\operatorname{Tmax}_{A L}^{h}(i)$ are the hourly minimum and maximum adjusted ALADIN temperature values respectively, and $\operatorname{Tmin}_{A L}^{d, a d j}(i)$ and $\operatorname{Tmax}_{A L}^{d, a d j}(i)$ are the daily minimum and maximum adjusted ALADIN temperature values respectively (Fig. 2). $\alpha$ is a parameter which can be tuned to balance the importance of the minimisation of differences between daily and hourly ALADIN minima and maxima and the minimisation of the jump between two consecutive days. For a value of $\alpha$ of zero, there would be no jump in values between consecutive days, but the values of $\operatorname{Tmin}_{A L}^{h}(i)$ and $\operatorname{Tmax}_{A L}^{h}(i)$ would be far from the values of $\operatorname{Tmin}_{A L}^{d, a d j}(i)$ and $\operatorname{Tmax}_{A L}^{d, a d j}(i)$. For an infinitely big value of $\alpha$, on the opposite, minimum and maximum 
Geosci. Model Dev. Discuss., doi:10.5194/gmd-2016-168, 2016

Manuscript under review for journal Geosci. Model Dev.

Published: 29 September 2016

(c) Author(s) 2016. CC-BY 3.0 License.

$T_{A L}^{h}(i)=a \times T_{S A F}^{h}+b$,

where $T_{A L}^{h}(i)$ is the hourly adjusted ALADIN temperature and $T_{S A F}^{h}$ is the hourly SAFRAN temperature from the chosen analogous date (step 6). As a result, eq. 2 transforms into:

$$
\begin{aligned}
Q(\alpha, a, b)= & {\left[a \times T_{S A F}^{h}(1 h)+b-T_{A L}^{h}(24 h, i-1)\right]^{2} } \\
& +\alpha\left[a \times \operatorname{Tmin}_{S A F}^{h}+b-\operatorname{Tmin}_{A L}^{d, a d j}(i)\right]^{2} \\
& +\alpha\left[a \times \operatorname{Tmax}_{S A F}^{h}+b-\operatorname{Tmax}_{A L}^{d, a d j}(i)\right]^{2} .
\end{aligned}
$$

By searching for the local minima $\delta Q / \delta a=0$ and $\delta Q / \delta b=0, a$ and $b$ can be determined, and the hourly adjusted ALADIN temperature can be obtained following eq. 3. This procedure is only applied for temperature, because the use of the maximum and minimum criterion can lead to important jumps between consecutive days, which is not the case for other variables (Table 1).

8. Finally, total precipitation is separated into rainfall and snowfall based on hourly adjusted temperature (a threshold of $1{ }^{\circ} \mathrm{C}$ is used for the transition from snow to rain, consistent with the approach used in SAFRAN). As mentioned before, inter-variable consistency is not guaranteed by quantile mapping. Consistency between temperature and precipitation is the most critical in this study, because we focus on mountain regions where snow plays an important role. As precipitation and temperature were corrected independently from each other (step 5), the relationship between temperature and precipitation may be modified by quantile mapping, so that the RCM rain and snow distributions may lose consistency. To avoid this, Olsson et al. (2015) separate their temperature data into wet and dry days before adjustment. In our case an additional quantile mapping against SAFRAN is applied for daily cumulated RCM rainfall and snowfall separately. Hourly adjusted RCM rainfall and snowfall are then determined as for total precipitation similar to step 7 .

\subsection{Method evaluation}

To evaluate our downscaling and bias adjustment method, adjusted outputs from the ALADIN RCM forced by ERA-Interim (1979-2010) were analysed. The evaluation was carried out for temperature and total precipitation, but also for the snow depth, which integrates all the meteorological variables considered in the downscaling and adjustment method. This allows evaluating the ability of our method to correctly represent integrated outputs computed using SURFEX/ISBA-Crocus from meteorological variables adjusted independently from each other. This is also usually done with river 
Geosci. Model Dev. Discuss., doi:10.5194/gmd-2016-168, 2016

Manuscript under review for journal Geosci. Model Dev.

Published: 29 September 2016

(c) Author(s) 2016. CC-BY 3.0 License.

discharge for downscaling methods used for hydrological applications (e.g. Lafaysse et al. (2014); Olsson et al. (2015)).

Different criteria were evaluated for each massif of the French Alps (Fig. 1), at every elevation band, and aggregated at the scale of the Northern French Alps (14 massifs) and the Southern French Alps (9 massifs), which represent regions with distinct climates (Durand et al., 2009b). Massifs are grouped in the Southern and Northern French Alps by calculating the mean value of temperature, precipitation or snow depth for a given altitude, which is then evaluated with the different criteria. For specific scores concerning the detection and the persistence of precipitation events (listed below), scores are first determined for each massif, and then an average score is calculated for each altitude for the different massifs of the Northern and the Southern French Alps. Some evaluations are presented for all altitudes in Sect. 3, others only for $1200 \mathrm{~m}$ a.s.l. (above sea level) and $2100 \mathrm{~m}$ a.s.l., in order to differentiate mid- and high altitudes, for the Vercors massif and the Northern and Southern Alps. Results for additional massifs are presented in the Supplementary Information (Figs. S1-S207). The two RCM grid points neighbour selection techniques and the three different learning periods presented in Sect. 2.4 were tested. The impact of using $6 \mathrm{~h}$ input RCM data instead of daily data was also tested, but yielded similar results (not shown). Only results based on daily input are presented because GCM/RCM outputs are often available at this time step on data distribution platforms such as the one of EURO-CORDEX.

The following evaluation criteria were used for temperature, total precipitation and snow depth:

- the seasonal average time series from 1979 to 2010 ,

- the mean annual cycle over 2 distinct periods : 1980-1994 and 1995-2010,

- the mean altitudinal gradient over 1979-2010 (determined only for each massif),

- the correlation and the ratio of standard deviations between RCM time series and SAFRAN for each variable and as a function of the integration time (from 1 day to several years) from 1979 to 2010 ,

- the cumulated probability density function (PDF) of daily variables over 1979-2010,

- the root mean square error (RMSE) and the mean bias over 1979-2010, computed over seasonal integration periods,

- scores specific to the detection of precipitation events over 1979-2010 : the probability of detection $\left(\mathrm{POD}=n_{h h} /\left(n_{h h}+n_{h d}\right)\right)$, the false alarm rate $\left(\mathrm{FAR}=n_{d h} /\left(n_{d h}+n_{h h}\right)\right)$, the probability of false detection (POFD $=n_{d h} /\left(n_{d h}+n_{d d}\right)$ ) and the true skill score (TSS = POD FAR), where $n_{h h}$ is the number of days which are wet in the reanalysis and wet in the adjusted $\mathrm{RCM}, n_{d d}$ the number of days which are dry in the reanalysis and dry in the adjusted RCM, $n_{h d}$ the number of days which are wet in the reanalysis but dry in the adjusted RCM and $n_{d h}$ 
Geosci. Model Dev. Discuss., doi:10.5194/gmd-2016-168, 2016

Manuscript under review for journal Geosci. Model Dev.

Published: 29 September 2016

(c) Author(s) 2016. CC-BY 3.0 License.

the number of days which are dry in the reanalysis but wet in the adjusted RCM (a threshold of $1 \mathrm{~kg} \mathrm{~m}^{-2} \mathrm{~d}^{-1}$ was considered for the occurrence of precipitation),

- scores for the duration and persistence of precipitation events over 1979-2010 (Wilby et al., 1998; Boé et al., 2006): the relative error on the probability of a dry day $\left(\operatorname{EPD}=\left(n_{d}^{R}-\right.\right.$ $\left.n_{d}^{S}\right) / n_{d}^{S}$ ), the relative error on the probability of a dry day following a dry day (EPDD = $\left.\left(n_{d-d}^{R} / n_{d}^{R}-n_{d-d}^{S} / n_{d}^{S}\right) /\left(n_{d-d}^{S} / n_{d}^{S}\right)\right)$, the relative error on the probability of a wet day following a wet day $\left(\mathrm{EPHH}=\left(n_{h-h}^{R} /\left(n-n_{d}^{R}\right)-n_{h-h}^{S} /\left(n-n_{d}^{S}\right)\right) /\left(n_{h-h}^{S} /\left(n-n_{d}^{S}\right)\right)\right)$ and the relative error on the mean duration of wet periods $\left(\mathrm{EHD}=\left(h d u r^{R}-h d u r^{S}\right) / h d u r^{S}\right)$, where $n_{d}^{R}$ and $n_{d}^{S}$ are the number of dry days in the RCM and in SAFRAN respectively, $n_{d-d}^{R}$ and $n_{d-d}^{S}$ the number of dry days following a dry day in the RCM and in SAFRAN respectively, $n_{h-h}^{R}$ and $n_{h-h}^{S}$ the number of wet days following a wet day in the RCM and in SAFRAN respectively, $n$ is the total number of days, and $h d u r^{R}$ and $h d u r^{S}$ the duration of wet periods in the RCM and in SAFRAN respectively. A threshold of $1 \mathrm{~kg} \mathrm{~m}^{-2} \mathrm{~d}^{-1}$ was considered for the occurrence of precipitation.

These criteria are classically employed (e.g. Boé et al., 2006; Vrac et al., 2007b; Lafaysse, 2011; Kotlarski et al., 2014) to assess (1) the ability of a model/a method to reproduce the statistical characteristics of the observed meteorological variables (through the RMSE, the mean bias, the ratio of standard deviations, the duration and persistence of precipitation events and the cumulated PDFs) and their spatial variability (through the altitudinal gradient and the analysis of different massifs), (2) its capacity to reproduce the low frequency variability of the observations, i.e. their chronology (through the analysis of seasonal average time series, the correlation as a function of the integration time, the detection of precipitation events), (3) its temporal transferability, i.e. its ability to reproduce the observed variables on a period different from the learning period (through the analysis of the mean annual cycle over two distinct periods, the seasonal average time series, etc.), and (4) its inter-variable consistency, which is assessed here by applying the evaluation metrics to an integrated output of the SURFEX/ISBA-Crocus model, the snow depth. When available, we compare our different results in Sect. 3 with the same criteria obtained for analog resampling based or transfer function algorithms by Lafaysse (2011) and Lafaysse et al. (2014), and occasionally for other downscaling and adjustment methods by Vrac et al. (2012) and Olsson et al. (2015).

\subsection{Simulations and variables considered}

The SURFEX/ISBA-Crocus model, hereafter Crocus, was forced with the ALADIN evaluation outputs downscaled to the massif scale and for each 300 m elevation and adjusted against SAFRAN via quantile mapping as explained in Sect. 2.4. The Crocus simulation was first initialised (soil temperature mainly) with a 20-year spin-up run. A summary of the variables considered as input and output of Crocus is presented in Table 1, where variables considered in the evaluation of the ADAMONT 
Geosci. Model Dev. Discuss., doi:10.5194/gmd-2016-168, 2016

Manuscript under review for journal Geosci. Model Dev.

Published: 29 September 2016

(c) Author(s) 2016. CC-BY 3.0 License.

method are highlighted. The snowpack depth and snow water equivalent (SWE) were evaluated, but

only the snowpack depth is shown.

\subsection{Configurations of the method}

The ADAMONT method was applied to the entire period 1980-2010 using different configurations, tested under several combinations. The selection of the RCM grid points closest to the SAFRAN massifs centroids/altitude levels was done either purely accounting for the horizontal distance (base case), and accounting for the elevation difference using an elevation factor of 50 and 100. Results with a value 50 (N50) are shown here. Different learning periods were tested to evaluate their impact : 1980-1994 and 1995-2010, which correspond to periods with contrasting meteorological (and snow) conditions linked to regime shifts (Reid et al., 2015), and the entire period from 1980 to 2010. The method was applied with (base case) or without ("no corr") the last adjustment step operating on the rainfall and snowfall separately. Table 2 presents a summary of the different configurations used for the evaluation (Sect. 2.5).

\section{Results}

\subsection{Spatial variability and statistical characteristics of the evaluated variables}

This section provides the evidenced needed to assess the ability of the ADAMONT method to reproduce the spatial variability (through the analysis of different massifs and the altitudinal gradient) and the statistical characteristics of SAFRAN for temperature, precipitation and snow depth.

Figure 3 presents the location of the Vercors massif and its average altitudinal gradient of temperature, precipitation and snow depth for the period 1980-2010 in the SAFRAN/Crocus reanalysis as well as downscaled/adjusted from the RCM output using our method. The shape of the altitudinal gradient of all three variables is well represented by our method compared to SAFRAN, which is also the case for other massifs (Figs. S1-S207). The computed temperature values are very similar to the one in SAFRAN. It is less the case for precipitation, with over- or underestimation depending on the learning period (Fig. 3) and the massif considered (Figs. S1-S207). A feature common to almost all massifs (Figs.3 and S1-S207) is the lower value of average precipitation for the learning period 1980-2010 compared to the other periods. Despite the differences in the magnitude of average precipitation in the adjusted RCM compared to SAFRAN, the magnitude of average snow depth in the different adjusted RCM simulations is remarkably close to results obtained using the reanalysis as meteorological input (Fig. 3), with slight differences depending on the massif (Figs. S1-S207). For all variables and all massifs, the difference between simulations using the two RCM grid points neighbour selection techniques is smaller than the difference induced by using different learning periods. 
Geosci. Model Dev. Discuss., doi:10.5194/gmd-2016-168, 2016

Manuscript under review for journal Geosci. Model Dev.

Published: 29 September 2016

(c) Author(s) 2016. CC-BY 3.0 License.

Figs. 4-12 display the mean bias and the RMSE for each adjusted RCM simulation compared to SAFRAN, for temperature, precipitation and snow depth, and for the Vercors massif and the Northern and Southern Alps.

For temperature, biases vary with elevation and for the different massifs (Figs. 4-6 and S1-S207), but lie always within $1 \mathrm{~K}$. Biases are generally smaller in autumn (SON) than for other seasons. RMSEs also vary with elevation and massifs, and can differ significantly between simulations using the two different RCM grid points neighbour selection techniques. For elevations above $\approx 2100 \mathrm{~m}$ a.s.l., stronger biases and higher RMSEs are found for simulations using the selection technique accounting for altitude differences (N50). This feature is also generally stronger in summer (JJA) than for other seasons. Temperature biases and RMSEs also depend on the learning period considered, the longer learning period 1980-2010 generally presenting smaller biases and RMSEs (Figs. 4-6 and S1-S207). This better performance of the 1980-2010 learning period is less visible in summer for elevations above $\approx 1500 \mathrm{~m}$ a.s.l.

For precipitation and snow depth, simulations without the ultimate quantile mapping on snowfall and rainfall are also presented (by definition it has no impact on temperature). It is clear from Figs. 712 and S1-S207 that without this ultimate correction (no corr), biases in precipitation and snow depth are much stronger and RMSEs much higher than when this correction is applied.

Apart from this specific point, biases in precipitation generally vary with altitude ( Figs. 7-9 and S1-S207), but less than for temperature (Figs. 4-6 and S1-S207). Biases remain smaller than $150 \mathrm{~kg}$ $\mathrm{m}^{-2}$ per month in absolute value, and are generally stronger in summer. RMSEs generally increase with altitude. Using different RCM grid points neighbour selection techniques has less impact on precipitation scores than for temperature, except that the N50 configuration yields more variability in scores with altitude. This is due to the choice of different grid points for different altitudes of a single massif, because precipitation is spatially more variable than temperature. The influence of the learning period on scores is also visible, especially in summer for the learning period 1980-2010, which presents a larger negative bias, as already mentioned above for altitudinal gradients.

For snow depth, biases never exceed $50 \mathrm{~cm}$ (Figs. 10-12 and S1-S207). Biases are smallest in autumn than for other seasons, similar to temperature (Figs. 4-6 and S1-S207). Summer biases at high altitudes are almost always negative, which cannot always be explained by a combination of positive biases in temperature and/or negative biases in precipitation, indicating the possible impact of other variables on snow depth (such as longwave radiation for example). Moreover, the large bias detected in summer precipitation for the learning period 1980-2010 is partly compensated by much smaller biases in summer temperature, resulting in snow depth biases which are generally only slightly more negative in summer than for the other learning periods. RMSEs increase with altitude, due to the effect of increased snow accumulation with altitude. Using the N50 configuration generally degrades scores at high elevations, similar to the effect on temperature. 
Geosci. Model Dev. Discuss., doi:10.5194/gmd-2016-168, 2016

Manuscript under review for journal Geosci. Model Dev.

Published: 29 September 2016

(c) Author(s) 2016. CC-BY 3.0 License.

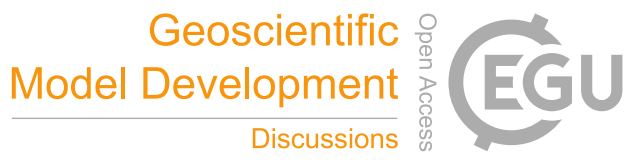

Figs. 13-15 represent the ratio of standard deviations between each adjusted RCM 1979-2010 simulation and SAFRAN for temperature, precipitation and snow depth and as a function of the integration time (from 1 day to several years). Ratios are displayed for the Vercors massif, and for the Northern and Southern Alps, for altitudes of $1200 \mathrm{~m}$ a.s.l. and $2100 \mathrm{~m}$ a.s.l.. If this ratio is lower than 1, it means that adjusted RCM simulations have a smaller standard deviation (i.e. variability) than SAFRAN. For temperature, the ratio of standard deviations is very close to 1 for integration times of 1 day to a few months. It varies more for longer integration times of 1 year or more. The differences between the two altitudinal levels considered or between massifs are very limited (Figs. 13 and S1S207). Similarly, choosing different learning periods or different neighbour selection techniques has little effect on the ratio of standard deviations. For precipitation, ratios of standard deviations are also close to 1 (generally between 0.8 and 1.2) for integration times of 1 day to 1 month. This result is similar to ratios of variance between daily RCMs adjusted with a Cumulative Distribution Functiontransform and observations for the Mediterranean region in Vrac et al. (2012). After 1 month of integration, ratios vary more, with under- or overestimation of variance depending on the massif, the learning period and the neighbour selection technique considered (Figs. 14 and S1-S207). For snow depth, the ratio does not vary until 1 month of integration approximately (Figs. 14 and S1-S207). After that, it varies much more with the integration time. Some differences can be noted for different altitudes, different massifs, but also for different learning periods and the two neighbour selection techniques considered.

Figs. 16-18 present the cumulated probability density functions (PDFs) of daily temperature, precipitation and snow depth at $1200 \mathrm{~m}$ a.s.l. and $2100 \mathrm{~m}$ a.s.l. for the Vercors massif, the Northern Alps and the Southern Alps. The distributions of daily temperature of adjusted RCM simulations are remarkably close to the distribution of SAFRAN/Crocus (Figs. 16 and S1-S207). The agreement is better than the one observed in Lafaysse (2011) and Lafaysse et al. (2014) between the different configurations of analog-based and transfer functions algorithms and SAFRAN for the Durance basin (see Fig.F.2 in Lafaysse (2011), and Fig.5 in Lafaysse et al. (2014)). Similar agreement is observed in Olsson et al. (2015) between two configurations of a distribution-based scaling method and observations in Finland. Only small differences are observed for different altitudes or different massifs (Figs. 16 and S1-S207), and the choice of the learning period or the neighbour selection technique has almost no impact on the PDF. For precipitation, the PDFs of adjusted RCM simulations are also very close to the PDF of SAFRAN, with a slight underestimation of moderate to high precipitation occurring for most massifs (Figs. 17 and S1-S207). This result is similar to the one observed in Lafaysse (2011) for the Durance basin (see Fig.11.7 therein). As for temperature, altitude and massif location have only small impact on the distribution, as well as the learning period and the neighbour selection technique considered. The distribution of snow depth, on the other hand, depends more on the massif considered and the altitude (Figs. 18 and S1-S207). As for precipitation, the moderate to high snow depths seem to be slightly underestimated for most massifs. The choice of the learning 
Geosci. Model Dev. Discuss., doi:10.5194/gmd-2016-168, 2016

Manuscript under review for journal Geosci. Model Dev.

Published: 29 September 2016

(c) Author(s) 2016. CC-BY 3.0 License.

period and the neighbour selection technique have also slightly more impact on snow depth PDFs than for temperature and precipitation. The fact that PDFs for temperature and precipitation are very close to the ones of SAFRAN is a logical consequence of using a quantile mapping approach. Moreover, the fact that it is also true for snow depth indicates that even if they are treated separately, the inter-variable consistency of the meteorological fields generated using our method is in general appropriate.

The capacity of the ADAMONT method to reproduce the duration and persistence of precipitation events can be assessed using data shown in Fig. 19. The ratio between the number of dry days and the number of rainy or snowy days is very correctly reproduced for every massif and altitude (Figs. 19 and S1-S207), the relative error on the probability of a dry day being lower than 5\%. This feature was also observed by Lafaysse (2011) in his study of the Durance basin (see Fig.11.10 therein). The persistence of dry and rainy/snowy events is generally underestimated (up to about $-30 \%$ ), which was also the case in Lafaysse (2011), even though the error depends on the massif and the altitude considered. In general, errors on the persistence of precipitation events are larger in the Southern Alps than the Northern Alps. Using different learning periods and different neighbour selection techniques has an impact on scores, but which is small compared to the influence of the massif or the altitude.

\subsection{Mean seasonal variations}

Figs. 20-22 represent the mean annual cycle of temperature, precipitation and snow depth for the different adjusted RCM simulations vs. the SAFRAN/Crocus reanalysis, for the period 1980-1994 and 1995-2010. This is evaluated for the Vercors massif, the Northern and Southern Alps, and at $1200 \mathrm{~m}$ a.s.l. and $2100 \mathrm{~m}$ a.s.1.. The mean annual cycle of temperature is very well reproduced for every massif and altitude (Figs. 20 and S1-S207). Using different neighbour selection techniques has a limited impact on the mean annual cycle. For precipitation, the mean annual cycle is relatively well reproduced (Figs. 21 and S1-S207). The choice of neighbour selection technique can have slightly more influence on the results than for temperature. For snow depth, the annual cycle is remarkably well reproduced, with peak snow depth in the core of winter (JFM), and no snow or reduced amounts in late summer months (JAS) (Figs. 22 and S1-S207). As for temperature, the impact of the neighbour selection technique is very limited. Concerning the choice of learning period, as already noted in Sect. 3.3, the ADAMONT method performs better during a period which corresponds to its learning period. This is visible for temperature ( Figs. 20 and S1-S207), less visible for precipitation ( Figs. 21 and S1-S207), and again visible to some extent for snow depth ( Figs. 22 and S1-S207).

\subsection{Interannual variability}

This section addresses the ability of the ADAMONT method to reproduce the low frequency variability of temperature, precipitation and snow depth in the SAFRAN/Crocus reanalysis. 
Geosci. Model Dev. Discuss., doi:10.5194/gmd-2016-168, 2016

Manuscript under review for journal Geosci. Model Dev.

Published: 29 September 2016

(c) Author(s) 2016. CC-BY 3.0 License.

The chronology of time series of seasonal averaged temperature, precipitation and snow depth from 1979 to 2010 is assessed in Figs. 23-25, for the Vercors massif and the Northern and Southern Alps at $1200 \mathrm{~m}$ a.s.l. and $2100 \mathrm{~m}$ a.s.l., in SAFRAN and the adjusted RCM. Temperature RCM time series are similar to SAFRAN, with an interannual variability which is well reproduced (Figs. 23 and S1-S207). Some significant differences appear when using different learning periods, with the adjusted RCM simulation using the 1980-1994 learning period being the closest to observations for the first part of time series (1979-1994), and the simulation with the 1995-2010 learning period performing better for the second part (1995-2010). Using different neighbour selection techniques has an impact on the time series of temperature which is generally smaller than the influence of the learning period. However, as already noted in Sect. 3.1, the agreement between observed and simulated time series is degraded for high altitudes under the spatial and altitudinal (N50) neighbour selection technique. The interannual variability of precipitation is also well reproduced for most massifs and altitudes (Figs. 24 and S1-S207), especially keeping in mind that the only forcing of our system comes from ERA-Interim reanalysis at the boundaries of the RCM domain. It is slightly less well reproduced in summer (JJA), as observed by Lafaysse (2011) for DSCLIM and the Durance basin (see Fig.10.1 therein). Differences between simulations using different learning periods mostly appear in summer (JJA). The underestimation of precipitation in summer for simulations using the learning period 1980-2010 also appears in Figs. 24 and S1-S207. The use of different neighbour selection techniques has a rather limited impact on time series of precipitation, whose magnitude depends on the massif and the altitude (Figs. 24 and S1-S207). For snow depth, the interannual variability is well reproduced in winter (DJF) and correctly reproduced in intermediate seasons (MAM and SON). Summer snow depths are generally underestimated, as already noted in Sect. 3.1, but represent a small portion of the annual snow accumulation. Similarly, time series using the spatial and altitudinal (N50) RCM grid points neighbour selection technique can be degraded at high altitudes, similarly to temperature.

Figs. 26-27 display the temporal correlation between each adjusted RCM 1979-2010 simulation and SAFRAN for temperature and precipitation and as a function of the integration time (from 1 day to several years). Correlations are displayed for the Vercors massif, and for the Northern and Southern Alps, for altitudes of $1200 \mathrm{~m}$ a.s.l. and $2100 \mathrm{~m}$ a.s.1.. Snow depth values were not included because of their cumulative nature. Correlations for temperature are very high for this type of downscaling/adjustment method (always above 0.8) for all massifs and altitudes until an integration time of a few months to 1 year (Figs. 26 and S1-S207), similar to Lafaysse (2011) (see Fig.F.21 therein). Differences between learning periods are negligible. As already observed in Sect. 3.1 and for time series above, the correlation is clearly degraded for high altitudes (above $\approx 2100 \mathrm{~m}$ a.s.1.) in simulations using the N50 neighbour selection technique. Precipitation also yield satisfying correlation

510 values for this type of downscaling/adjustment method (always above 0.4) until a few months integration time, which vary depending on the massif considered(Figs. 27 and S1-S207). Correlations 
Geosci. Model Dev. Discuss., doi:10.5194/gmd-2016-168, 2016

Manuscript under review for journal Geosci. Model Dev.

Published: 29 September 2016

(c) Author(s) 2016. CC-BY 3.0 License.

are generally similar or even better than the ones observed in Lafaysse (2011) for various statistical downscaling models and different configurations of the ALADIN RCM (see Fig.12.10 therein). The use of the N50 neighbour selection technique increases or decreases correlation values depending on

the massif and the altitude considered. It should be noted that although simulations using the 19802010 learning period underestimate summer precipitation, this effect is not visible on correlation, indicating that it does not affect the synchronisation between adjusted RCM and SAFRAN, only the amounts simulated. In fact the choice of the learning period has a limited effect on correlation, at least up to integration times of a few months. It should also be noticed that correlations are higher at the scale of the Northern and Southern Alps than at the massif scale. This scale dependence of precipitation downscaling skill was also illustrated by Gangopadhyay et al. (2004) or Mezghani and Hingray (2009).

Scores for the detection of precipitation events are presented in Fig. 28, for the Vercors massif, the Northern and Southern Alps, and for altitudes of $1200 \mathrm{~m}$ a.s.l. and $2100 \mathrm{~m}$ a.s.l.. Scores vary depending on massifs and altitude, but a general pattern emerges (Figs. 28 and S1-S207). The probability of detection (POD) is the highest, with values between 0.55 and 0.8 , very similar to Lafaysse (2011) (see Figs. 11.14 and 12.8 therein). The false alarm rate (FAR) is rather low (always below 0.5 ), as well as the probability of false detection (POFD, below 0.2). True skill scores (TSS) are generally better for massifs of the Northern Alps than the Southern Alps, where PODs are lower and FAR much higher. Such results indicate a good performance of our method in detecting precipitation events. Using different learning periods has a rather limited impact on the detection of precipitation. The choice of the neighbour selection technique has a limited influence at low to mid-altitudes, but increases above $\approx 2100 \mathrm{~m}$ a.s.1..

\section{Discussion}

This study introduces and evaluates a downscaling and adjustment method for daily RCM model output using a reanalysis of hourly meteorological data tailored for mountain regions as a pseudoobservation database (SAFRAN). The ADAMONT method applies quantile mapping depending on the season and the weather type, and uses analogue dates from the observation database to disaggregate the daily adjusted/downscaled meteorological data into hourly time series. This section discusses the main limits of the method described and evaluated here, and the limits of the evaluation method itself.

\subsection{Transferability in time}

The temporal transferability of the ADAMONT method, i.e. its capacity to apply adequately to a period which is different from the learning period, can be evaluated from results in Sects. 3.1, 3.3 
Geosci. Model Dev. Discuss., doi:10.5194/gmd-2016-168, 2016

Manuscript under review for journal Geosci. Model Dev.

Published: 29 September 2016

(c) Author(s) 2016. CC-BY 3.0 License.

Figs.3, 7-9, 24 and S1-S207 showed a general underestimation of average precipitation for the learning period 1980-2010 compared to the other periods, especially during the summer season, and is attributed to the difficulties of the method to handle the infrequent high precipitation values which occur in the summertime, and whose distribution is highly dependent on the learning period considered. This underestimation highlights a weakness of our method : the quantile mapping correction is less robust for values higher than the 99.5th quantile, and is dependent on the period considered. For simulations with the longest learning period 1980-2010, values higher than the 99.5th quantile in the RCM, which were much lower than the corresponding values in SAFRAN, could not be adjusted correctly, resulting in an underestimation of cumulated precipitation.

555 Figs. 23-25, 20-22 and S1-S207 revealed some significant differences appearing when using different learning periods, with the adjusted RCM simulation using the 1980-1994 learning period being the closest to observations for the first part of time series (1979-1994), and the simulation with the 1995-2010 learning period performing better for the second part (1995-2010). This feature is generally most visible in summer. It denotes a limit in the temporal transferability of the ADAMONT method, which was also the case in Lafaysse (2011) for the analog-based and transfer functions algorithms (see Figs. 11.11 and 11.12 therein). Using the longer learning period 1980-2010 generally allows for a good compromise, except for precipitation during summer months as already noted above.

However, one should keep in mind the limits of evaluating the temporal transferability of our method. The first is the temporal heterogeneities of reanalysis data (Sterl, 2004; Vidal et al., 2010) used here as forcing for the RCM (ERA-Interim) or for downscaling/adjustment and evaluation purposes (SAFRAN renalysis). These heterogeneities are especially marked in summer in the SAFRAN reanalysis, when most observations from mountain stations are not available. The second is the fact that variations which will occur in the future climate will be much stronger than the variations which can be tested on our evaluation period.

\subsection{Impact of the spatial selection technique}

The impact of the RCM grid point neighbour selection technique was illustrated in Sects. 3.1 and 3.3. Indeed, Figs. 4-12, 23-25, 26-27 and S1-S207 showed a clear degradation of scores for elevations above $\approx 2100 \mathrm{~m}$ a.s.l. using the spatial and altitudinal (N50) selection technique. This is linked to the scarcity of high altitude grid points in ALADIN compared to SAFRAN, resulting in grid points being selected several tens of kilometers from the SAFRAN centroid of most massifs (see Fig. 3 and Figs. S1-S207 for the location of selected grid points). This feature thus depends on the location of massifs relative to high-altitude grid points in ALADIN. For example, most Southern Alps massifs are affected by it, except the southernmost massifs of Ubaye, Alpes Azur and Mercantour (Figs. S1-S207), which are located less than $15 \mathrm{~km}$ from high-altitude points. This shows that, although it seems appealing to select RCM grid points at elevations matching the elevation of the 
Geosci. Model Dev. Discuss., doi:10.5194/gmd-2016-168, 2016

Manuscript under review for journal Geosci. Model Dev.

Published: 29 September 2016

(c) Author(s) 2016. CC-BY 3.0 License.

observation dataset, rather than using RCM grid points with a potentially large elevation difference (hence leading to stronger downscaling/adjustment), in practice the results are far more homogeneous and quantitatively generally equivalent or better when concentrating only on the horizontal distance between the RCM grid points and the observation dataset.

\subsection{Inter-variable consistency}

The lack of explicitly enforced inter-variable consistency of the quantile mapping method can be a major disadvantage. As we focus on a mountainous region, where snow is important, the consistency between temperature and precipitation phase was crucial. We thus performed an additional quantile mapping for daily rainfall and snowfall separately. The impact of this ultimate correction was assessed in Sect. 3.1. Figs. 7-12 and S1-S207 showed that without this ultimate correction (no corr), biases were much stronger and RMSEs much higher than with this ultimate correction, highlighting its importance.

The inter-variable consistency of the ADAMONT method was indirectly assessed by applying the evaluation metrics described above to an integrated output of the Crocus model, the snow depth, which was computed from meteorological variables adjusted independently from each other. As mentioned above, snow depth results are generally satisfying, which tend to indicate a good intervariable consistency. Metrics for snow depths are often related to metrics for temperature and precipitation, even though sometimes they cannot be explained only by these two variables (for example the analysis of biases in Sect. 3.1), indicating the probable influence of other variables not directly analysed here such as longwave radiation.

\subsection{Limits of the evaluation method}

The spatial consistency of the ADAMONT method has not been evaluated other than by using spatial averages. In future works, it would be necessary to test it by evaluating spatial correlations (for example using metrics described in Kotlarski et al. (2014)), or by using integrated variables requiring spatial variability, such as snow cover area or river discharges.

In this study, we evaluated our method using only the ALADIN-Climate RCM. However, Olsson et al. (2015) showed that the choice of adjusted RCM could have a non-negligible impact on the performance of the adjustment method. Evaluation using another RCM could thus prove useful, even

610 though we would have to use RCM outputs run on the same spatial domain as the ALADIN-Climate $\mathrm{RCM}$ in order to compare them.

\section{Conclusions}

A new method to downscale and adjust climate model projections - called ADAMONT - (ADAptation of RCM outputs to MOuNTain regions) - was introduced, which provides hourly adjusted out- 
Geosci. Model Dev. Discuss., doi:10.5194/gmd-2016-168, 2016

Manuscript under review for journal Geosci. Model Dev.

Published: 29 September 2016

(c) Author(s) 2016. CC-BY 3.0 License.

615 puts of temperature, precipitation, wind speed, humidity and short- and longwave radiation necessary to force energy balance land surface (impact) models. Daily outputs from an RCM were downscaled at the massif scale and for every $300 \mathrm{~m}$ elevation and adjusted against the SAFRAN hourly meteorological reanalysis using a quantile mapping approach. This method was tested using outputs from the ALADIN-Climate RCM driven by ERA-Interim reanalysis, which were evaluated against SAFRAN. Direct outputs of the downscaling and bias-adjustment, namely temperature and total precipitation, as well as an indirect output, namely snow depth, computed by the SURFEX/ISBA-Crocus model from meteorological variables corrected independently from each other, were evaluated. The impact of the learning period was tested, as well as the method to select neighbouring RCM grid points. Evaluation was carried out following four main concerns : (1) the ability of the ADAMONT method to reproduce the spatial (especially altitudinal) variability and the statistical characteristics of SAFRAN variables, (2) its ability to reproduce the low frequency variability, i.e. the chronology, of SAFRAN, through the analysis of the interannual variability and the annual cycle of adjusted variables (3) the temporal transferability of the method, and (4) its inter-variable consistency.

In general, the performance of the ADAMONT method concerning temperature is better than for precipitation. However, evaluation metrics for precipitation are generally similar or even better than the metrics evaluated in Lafaysse (2011) and Lafaysse et al. (2014) for other types of algorithms (analog-based or transfer functions), which is satisfying. Snow depth yields good results, considering its integrated nature, i.e. the fact that it was computed from variables corrected independently. A good inter-variable consistency seems to be obtained using this method, at least as far as snow depth is concerned. The impact of the learning period depends on the evaluation metric considered, but a general feature of the ADAMONT method is a certain limit in its temporal transferability. The best solution is probably to choose the longest possible learning period. However, a weakness in our method concerning precipitation is the lower robustness of the quantile mapping adjustment for values higher than the 99.5th quantile, which is highly dependent on the period considered, and therefore hard to estimate in a robust way. In our case, most errors are found in the summertime, which does not hamper the use of the ADAMONT method for issues related to seasonal snow. For precipitation and snow depth, the importance of the ultimate quantile mapping applied on snowfall and rainfall was demonstrated. Using a more complex neighbour selection technique relying on spatial but also altitudinal proximity between SAFRAN massif centroids and RCM grid points either had no impact on the metrics or degraded them for altitudes higher than $2100 \mathrm{~m}$ a.s.l.. As a consequence, the simple spatial neighbour selection technique will be retained for future applications of the method.

Our perspective is to apply this generic method to outputs from the EURO-CORDEX (Jacob et al., 2014) simulations - 10 different RCMs forced by different GCMs under 4 representative concentration pathways scenarios (RCPs) over Europe - in order to adjust a large ensemble of climate and snow condition projections for the $21^{s t}$ century, and estimate the uncertainty associated. For the 
Geosci. Model Dev. Discuss., doi:10.5194/gmd-2016-168, 2016

Manuscript under review for journal Geosci. Model Dev.

Published: 29 September 2016

(c) Author(s) 2016. CC-BY 3.0 License.

present study, we worked on a small domain covering only France, so that it was well-constrained, to evaluate the method and not the output of the RCM itself. In the framework of EURO-CORDEX, as we will work with RCMs driven by GCMs, the objective, on the contrary, will be to work on a much larger domain covering all of Europe, in order to analyse results depending less on the biases of GCMs. The ADAMONT method makes it possible to quickly process a large number of RCM model runs, making it compliant with the requirements of multi-model / multi-scenarios approaches. The method presented will also be useful for other applications using impact models which require downscaled and adjusted sub-diurnal meteorological inputs, such as avalanche hazard (Castebrunet

660 et al., 2014), agriculture and pastoral exploitation (Calvet et al., 2008), forest management (Deckmyn et al., 2008; Fontes et al., 2010), ecosystems (Saccone et al., 2013), glacier mass balance and hazards (Gerbaux et al., 2005; Gilbert et al., 2012), mountain hydrology (Lafaysse et al., 2014), winter tourism (François et al., 2014; Spandre et al., 2016), etc.

\section{Code availability}

665 The code of the ADAMONT v1.0 method is available upon request. Please contact Deborah Verfaillie (deborah.verfaillie@meteo.fr) or Michel Déqué (michel.deque@meteo.fr) to obtain it.

Acknowledgements. This study benefited from funding from the French Ministry for Ecology (MEEM) through the GICC program and ONERC, in the framework of the ADAMONT project. CNRM/CEN is part of LabEx OSUG@2020 (ANR10LABX56). 
Geosci. Model Dev. Discuss., doi:10.5194/gmd-2016-168, 2016

Manuscript under review for journal Geosci. Model Dev.

Published: 29 September 2016

(c) Author(s) 2016. CC-BY 3.0 License.

\section{References}

Abegg, B., Agrawala, S., Crick, F., and de Montfalcon, A.: Climate change impacts and adaptation in winter tourism, in: Climate Change in the European Alps, edited by Agrawala, S., pp. 25-60, OECD Paris, doi:10.1787/9789264031692-en, 2007.

Addor, N., Rohrer, M., Furrer, R., and Seibert, J.: Propagation of biases in climate models from the synoptic to the regional scale: Implications for bias adjustment, J. Geophys. Res. - Atmos., 121, 2075-2089, doi:10.1002/2015JD024040, 2016.

Alexandru, A., de Elia, R., and Laprise, R.: Internal variability in regional climate downscaling at the seasonal scale, Mon. Weather Rev., 135, 3221-3238, doi:http://dx.doi.org/10.1175/MWR3456.1, 2007.

Beniston, M.: Variations of snow depth and duration in the Swiss Alps over the last 50 years: links to changes in large-scale climatic forcings, Climatic Change, 36, 281-300, doi:10.1023/A:1005310214361, 1997.

Berg, P., Bosshard, T., and Yang, W.: Model consistent pseudo-observations of precipitation and their use for bias correcting regional climate models, Climate, 3, 118-132, doi:10.3390/cli3010118, 2015.

Boé, J., Terray, L., Habets, F., and Martin, E.: A simple statistical-dynamical downscaling scheme based on weather types and conditional resampling, J. Geophys. Res. - Atmos., 111, doi:10.1029/2005JD006889, 2006.

Boé, J., Terray, L., Habets, F., and Martin, E.: Statistical and dynamical downscaling of the Seine basin climate for hydro-meteorological studies, Int. J. Climatol., 27, 1643-1655, doi:10.1002/joc.1602, 2007.

Boulangeat, I., Georges, D., Dentant, C., Bonet, R., Van Es, J., Abdulhak, S., Zimmermann, N., and Thuiller, W.: Anticipating the spatio-temporal response of plant diversity and vegetation structure to climate and land use change in a protected area, Ecography, 37, 1230-1239, doi:10.1111/ecog.00694, 2014.

Brun, E., Martin, E., Simon, V., Gendre, C., and Coléou, C.: An energy and mass model of snow cover suitable for operational avalanche forecasting, J. Glaciol., 35, 333 - 342, 1989.

Brun, E., David, P., Sudul, M., and Brunot, G.: A numerical model to simulate snow-cover stratigraphy for operational avalanche forecasting, J. Glaciol., 38, 13 - 22, http://refhub.elsevier.com/S0165-232X(14)00138-4/ rf0155, 1992.

Calvet, J.-C., Gibelin, A.-L., Roujean, J.-L., Martin, E., Le Moigne, P., Douville, H., and Noilhan, J.: Past and future scenarios of the effect of carbon dioxide on plant growth and transpiration for three vegetation types of southwestern France, Atmos. Chem. Phys., 8, 397-406, doi:10.5194/acp-8-397-2008, 2008.

Castebrunet, H., Eckert, N., Giraud, G., Durand, Y., and Morin, S.: Projected changes of snow conditions and avalanche activity in a warming climate: the French Alps over the 2020-2050 and 2070-2100 periods, The Cryosphere, 8, 1673-1697, doi:10.5194/tc-8-1673-2014, 2014.

Christensen, J., Boberg, F., Christensen, O., and Lucas-Picher, P.: On the need for bias correction of regional climate change projections of temperature and precipitation, Geophys. Res. Lett., 35 , doi:10.1029/2008GL035694, 2008.

Colin, J., Déqué, M., Radu, R., and Somot, S.: Sensitivity study of heavy precipitation in Limited Area Model climate simulations: influence of the size of the domain and the use of the spectral nudging technique, Tellus A, 62, 591-604, doi:10.1111/j.1600-0870.2010.00467.x, 2010.

Dayon, G., Boé, J., and Martin, E.: Transferability in the future climate of a statistical downscaling method for precipitation in France, J. Geophys. Res. - Atmos., 120, 1023-1043, doi:10.1002/2014JD022236, 2015. 
Geosci. Model Dev. Discuss., doi:10.5194/gmd-2016-168, 2016

Manuscript under review for journal Geosci. Model Dev.

Published: 29 September 2016

(c) Author(s) 2016. CC-BY 3.0 License.

Deckmyn, G., Verbeeck, H., De Beeck, M., Vansteenkiste, D., Steppe, K., and Ceulemans, R.: ANAFORE: a stand-scale process-based forest model that includes wood tissue development and labile carbon storage in trees, Ecol. Model., 215, 345-368, doi:10.1016/j.ecolmodel.2008.04.007, 2008

Dee, D. P., Uppala, S. M., Simmons, A. J., Berrisford, P., Poli, P., Kobayashi, S., Andrae, U., Balmaseda, M. A., Balsamo, G., Bauer, P., Bechtold, P., Beljaars, A. C. M., van de Berg, L., Bidlot, J., Bormann, N., Delsol, C., Dragani, R., Fuentes, M., Geer, A. J., Haimberger, L., Healy, S. B., Hersbach, H., Hólm, E. V., Isaksen, L., Kålberg, P., Köhler, M., Matricardi, M., McNally, A. P., Monge-Sanz, B. M., Morcrette, J.-J., Park, B.-K., Peubey, C., de Rosnay, P., Tavolato, C., Thépaut, J.-N., and Vitart, F.: The ERA-Interim reanalysis: configuration and performance of the data assimilation system, Quart. J. Roy. Meteor. Soc., 137, 553-597, doi:10.1002/qj.828, 2011.

Déqué, M.: Frequency of precipitation and temperature extremes over France in an anthropogenic scenario: Model results and statistical correction according to observed values, Global Planet. Change, 57, 16-26, doi:10.1016/j.gloplacha.2006.11.030, 2007.

Déqué, M. and Somot, S.: Analysis of heavy precipitation for France using high resolution ALADIN RCM simulations, Idöjàràs Quaterly Journal of the Hungarian Meteorological Service, 112, 179-190, 2008.

Driouech, F., Déqué, M., and Mokssit, A.: Numerical simulation of the probability distribution function of precipitation over Morocco, Clim. Dynam., 32, 1055-1063, doi:10.1007/s00382-008-0430-6, 2009.

DSF: L'observatoires - Indicateurs et Analyses., Tech. rep., Domaines Skiables de France, http://www. domaines-skiables.fr/downloads/uploads/OBSERVATOIRERecueilIndicateur2011BD.pdf., 2011.

Durand, Y., Brun, E., Mérindol, L., Guyomarc'h, G., Lesaffre, B., and Martin, E.: A meteorological estimation of relevant parameters for snow models, Ann. Glaciol., 18, 65-71, http://www.igsoc.org/annals/18/igs_ annals_vol18_year1993_pg65-71.html, 1993.

Durand, Y., Giraud, G., Brun, E., Mérindol, L., and Martin, E.: A computer-based system simulating snowpack structures as a tool for regional avalanche forecasting, J. Glaciol., 45, 469-484, 1999.

Durand, Y., Giraud, G., Laternser, M., Etchevers, P., Mérindol, L., and Lesaffre, B.: Reanalysis of 47 Years of Climate in the French Alps (1958-2005): Climatology and Trends for Snow Cover, J. Appl. Meteor. Climat., 48, 2487-2512, doi:10.1175/2009JAMC1810.1, 2009a.

Durand, Y., Giraud, G., Laternser, M., Etchevers, P., Mérindol, L., and Lesaffre, B.: Reanalysis of 44 Yr of Climate in the French Alps (1958-2002): Methodology, Model Validation, Climatology, and Trends for Air Temperature and Precipitation., J. Appl. Meteor. Climat., 48, 429-449, doi:10.1175/2008JAMC1808.1, $2009 \mathrm{~b}$.

Fontes, L., Bontemps, J.-D., Bugmann, H., Van Oijen, M., Gracia, C., Kramer, K., Lindner, M., Rötzer, T., and Skovsgaard, J.: Models for supporting forest management in a changing environment, Forest Systems, 19, $8-29,2010$.

Fowler, H., Blenkinsop, S., and Tebaldi, C.: Linking climate change modelling to impacts studies: recent advances in downscaling techniques for hydrological modelling, Int. J. Climatol., 27, 1547-1578, doi:10.1002/joc.1556, 2007.

François, B., Hingray, B., Creutin, J., and Hendrickx, F.: Estimating water system performance under climate change: influence of the management strategy modeling, Water Resour. Manag., 29, 4903-4918, doi:10.1007/s11269-015-1097-5, 2015. 
Geosci. Model Dev. Discuss., doi:10.5194/gmd-2016-168, 2016

Manuscript under review for journal Geosci. Model Dev.

Published: 29 September 2016

(c) Author(s) 2016. CC-BY 3.0 License.

François, H., Morin, S., Lafaysse, M., and George-Marcelpoil, E.: Crossing numerical simulations of snow conditions with a spatially-resolved socio-economic database of ski resorts: A proof of concept in the French Alps, Cold Regions Science and Technology, 108, 98-112, doi:10.1016/j.coldregions.2014.08.005, 2014.

Gangopadhyay, S., Clark, M., Werner, K., Brandon, D., and Rajagopalan, B.: Effects of spatial and temporal aggregation on the accuracy of statistically downscaled precipitation estimates in the upper Colorado River basin, J. Hydrometeorol., 5, 1192-1206, doi:http://dx.doi.org/10.1175/JHM-391.1, 2004.

Gerbaux, M., Genthon, C., Etchevers, P., Vincent, C., and Dedieu, J.: Surface mass balance of glaciers in the French Alps: distributed modeling and sensitivity to climate change, J. Glaciol., 51, 561-572, doi:10.3189/172756505781829133, 2005

Gilbert, A., Vincent, C., Wagnon, P., Thibert, E., and Rabatel, A.: The influence of snow cover thickness on the thermal regime of Tête Rousse Glacier (Mont Blanc range, $3200 \mathrm{~m}$ asl): Consequences for outburst flood hazards and glacier response to climate change, J. Geophys. Res.: Earth, 117, doi:10.1029/2011JF002258, 2012.

Giorgi, F. and Mearns, L. O.: Approaches to the simulation of regional climate change: a review, Rev. Geophys., 29, 191-216, doi:10.1029/90RG02636, 1991.

Giorgi, F., Jones, C., and Asrar, G. R.: Addressing climate information needs at the regional level: the CORDEX framework, World Meteorol. Organ., 58, 175-183, 2009.

Gobiet, A., Suklitsch, M., and Heinrich, G.: The effect of empirical-statistical correction of intensitydependent model errors on the temperature climate change signal, Hydrol. Earth Syst. Sc., 19, 4055-4066, doi:10.5194/hess-19-4055-2015, 2015.

770 Gottardi, F., Obled, C., Gailhard, J., and Paquet, E.: Statistical reanalysis of precipitation fields based on ground network data and weather patterns: Application over French mountains, Journal of Hydrology, doi:10.1016/j.jhydrol.2012.02.014, 2012.

Hantel, M. and Hirtl-Wielke, L.-M.: Sensitivity of Alpine snow cover to European temperature, Int. J. Climatol., 27, 1265-1275, doi:10.1002/joc.1472, 2007.

IPCC: Climate Change 2013: The Physical Science Basis. Contribution of Working Group I to the Fifth Assessment Report of the Intergovernmental Panel on Climate Change [Stocker, T.F., D. Qin, G.-K. Plattner, M. Tignor, S.K. Allen, J. Boschung, A. Nauels, Y. Xia, V. Bex and P.M. Midgley (eds.)], Cambridge University Press, Cambridge, United Kingdom and New York, NY, USA, 1535 pp, 2013.

IPCC: Climate Change 2014: Impacts, Adaptation, and Vulnerability. Part A: Global and Sectoral Aspects.

Contribution of Working Group II to the Fifth Assessment Report of the Intergovernmental Panel on Climate Change [Field, C.B., V.R. Barros, D.J. Dokken, K.J. Mach, M.D. Mastrandrea, T.E. Bilir, M. Chatterjee, K.L. Ebi, Y.O. Estrada, R.C. Genova, B. Girma, E.S. Kissel, A.N. Levy, S. MacCracken, P.R. Mastrandrea, and L.L. White (eds.)], Cambridge University Press, Cambridge, United Kingdom and New York, NY, USA, $1132 \mathrm{pp}, 2014 \mathrm{a}$.

IPCC: Climate change 2014: Impacts, Adaptation, and Vulnerability. Part B: Regional Aspects. Contribution of Working Group II to the Fifth Assessment Report of the Intergovernmental Panel on Climate Change [Barros, V.R., C.B. Field, D.J. Dokken, M.D. Mastrandrea, K.J. Mach, T.E. Bilir, M. Chatterjee, K.L. Ebi, Y.O. Estrada, R.C. Genova, B. Girma, E.S. Kissel, A.N. Levy, S. MacCracken, P.R. Mastrandrea, and L.L. 
Geosci. Model Dev. Discuss., doi:10.5194/gmd-2016-168, 2016

Manuscript under review for journal Geosci. Model Dev.

Published: 29 September 2016

(c) Author(s) 2016. CC-BY 3.0 License.

White (eds.)], Cambridge University Press, Cambridge, United Kingdom and New York, NY, USA, 688 pp, 2014b.

IPCC: Climate Change 2014: Mitigation of Climate Change. Contribution of Working Group III to the Fifth Assessment Report of the Intergovernmental Panel on Climate Change [Edenhofer, O., R. Pichs-Madruga, Y. Sokona, E. Farahani, S. Kadner, K. Seyboth, A. Adler, I. Baum, S. Brunner, P. Eickemeier, B. Kriemann, J. Savolainen, S. Schlömer, C. von Stechow, T. Zwickel and J.C. Minx (eds.)], Cambridge University Press, Cambridge, United Kingdom and New York, NY, USA, 1435 pp, 2014c.

Jacob, D., Petersen, J., Eggert, B., Alias, A., Christensen, O. B., Bouwer, L. M., Braun, A., Colette, A., Déqué, M., Georgievski, G., Georgopoulou, E., Gobiet, A., Menut, L., Nikulin, G., Haensler, A., Hempelmann, N., Jones, C., Keuler, K., Kovats, S., Kröner, N., Kotlarski, S., Kriegsmann, A., Martin, E., van Meijgaard, E., Moseley, C., Pfeifer, S., Preuschmann, S., Radermacher, C., Radtke, K., Rechid, D., Rounsevell, M., Samuelsson, P., Somot, S., Soussana, J.-F., Teichmann, C., Valentini, R., Vautard, R., Weber, B., and Yiou, P.: EURO-CORDEX: new high-resolution climate change projections for European impact research, Reg. Environ. Change, 14, 563-578, doi:10.1007/s10113-013-0499-2, 2014.

Jomelli, V., Brunstein, D., Déqué, M., Vrac, M., and Grancher, D.: Impacts of future climatic change (20702099) on the potential occurrence of debris flows: a case study in the Massif des Ecrins (French Alps), Climatic Change, 97, 171-191, doi:10.1007/s10584-009-9616-0, 2009.

Kotlarski, S., Bosshard, T., Lüthi, D., Pall, P., and Schär, C.: Elevation gradients of European climate change in the regional climate model COSMO-CLM, Climatic change, 112, 189-215, doi:10.1007/s10584-011-01955,2012

Kotlarski, S., Keuler, K., Christensen, O. B., Colette, A., Déqué, M., Gobiet, A., Goergen, K., Jacob, D., 810 Lüthi, D., van Meijgaard, E., G. Nikulin, G., Schär, C., Teichmann, C., Vautard, R., Warrach-Sagi, K., and Wulfmeyer, V.: Regional climate modeling on European scales: a joint standard evaluation of the EUROCORDEX RCM ensemble, Geosci. Model Dev., 7, 1297-1333, doi:10.5194/gmd-7-1297-2014, 2014.

Lafaysse, M.: Changement climatique et régime hydrologique d'un bassin alpin. Génération de scénarios sur la Haute-Durance, méthodologie d'évaluation et incertitudes associées, Ph.D. thesis, Université Toulouse III-Paul Sabatier, 2011.

Lafaysse, M., Morin, S., Coleou, C., Vernay, M., Serca, D., Besson, F., Willemet, J.-M., Giraud, G., and Durand, Y.: Towards a new chain of models for avalanche hazard forecasting in French mountain ranges, including low altitude mountains, in: Proceedings of International Snow Science Workshop Grenoble-Chamonix Mont-Blanc, pp. 162-166, CEN, http://arc.lib.montana.edu/snow-science/objects/ISSW13_paper_O1-02. pdf, 2013.

Lafaysse, M., Hingray, B., Mezghani, A., Gailhard, J., and Terray, L.: Internal variability and model uncertainty components in future hydrometeorological projections: The Alpine Durance basin, Water Resources Research, 50, 3317-3341, 2014.

Maraun, D.: Bias correction, quantile mapping, and downscaling: Revisiting the inflation issue, J. Climate, 26, 2137-2143, doi:10.1175/JCLI-D-12-00821.1, 2013.

Maraun, D., Wetterhall, F., Ireson, A., Chandler, R., Kendon, E., Widmann, M., Brienen, S., Rust, H., Sauter, T., Themeß1, M., et al.: Precipitation downscaling under climate change: Recent developments to bridge the gap between dynamical models and the end user, Rev. Geophys., 48, doi:10.1029/2009RG000314, 2010. 
Geosci. Model Dev. Discuss., doi:10.5194/gmd-2016-168, 2016

Manuscript under review for journal Geosci. Model Dev.

Published: 29 September 2016

(c) Author(s) 2016. CC-BY 3.0 License.

Martin, E., Brun, E., and Durand, Y.: Sensitivity of the French Alps snow cover to the variation of climatic variables, Ann. Geophys., 12, 469-477, doi:10.1007/s00585-994-0469-6, 1994.

Masson, V., Le Moigne, P., Martin, E., Faroux, S., Alias, A., Alkama, R., Belamari, S., Barbu, A., Boone, A., Bouyssel, F., Brousseau, P., Brun, E., Calvet, J.-C., Carrer, D., Decharme, B., Delire, C., Donier, S., Essaouini, K., Gibelin, A.-L., Giordani, H., Habets, F., Jidane, M., Kerdraon, G., Kourzeneva, E., Lafaysse, M., Lafont, S., Lebeaupin Brossier, C., Lemonsu, A., Mahfouf, J.-F., Marguinaud, P., Mokhtari, M., Morin, S., Pigeon, G., Salgado, R., Seity, Y., Taillefer, F., Tanguy, G., Tulet, P., Vincendon, B., Vionnet, V., and Voldoire, A.: The SURFEXv7.2 land and ocean surface platform for coupled or offline simulation of Earth surface variables and fluxes, Geoscientific Model Development, 6, 929-960, doi:10.5194/gmd-6-929-2013, 2013.

Maurer, E. P. and Pierce, D. W.: Bias correction can modify climate model simulated precipitation changes without adverse effect on the ensemble mean, Hydrol. Earth Syst. Sc., 18, 915-925, doi:10.5194/hess-18915-2014, 2014

Mezghani, A. and Hingray, B.: A combined downscaling-disaggregation weather generator for stochastic generation of multisite hourly weather variables over complex terrain: Development and multi-scale validation for the Upper Rhone River basin, J. Hydrol., 377, 245-260, doi:10.1016/j.jhydrol.2009.08.033, 2009.

Michelangeli, P.-A., Vautard, R., and Legras, B.: Weather regimes: Recurrence and quasi stationarity, J. Atmos. Sci., 52, 1237-1256, doi:http://dx.doi.org/10.1175/1520-0469(1995)052<1237:WRRAQS>2.0.CO;2, 1995.

Olsson, T., Jakkila, J., Veijalainen, N., Backman, L., Kaurola, J., and Vehviläinen, B.: Impacts of climate change on temperature, precipitation and hydrology in Finland-studies using bias corrected Regional Climate Model data, Hydrol. Earth Sys. Sci., 19, 3217-3238, doi:10.5194/hess-19-3217-2015, 2015.

Piazza, M., Boé, J., Terray, L., Pagé, C., Sanchez-Gomez, E., and Déqué, M.: Projected 21st century snowfall changes over the French Alps and related uncertainties, Climatic Change, 122, 583-594, doi:10.1007/s10584-013-1017-8, 2014.

Rauscher, S. A., Coppola, E., Piani, C., and Giorgi, F.: Resolution effects on regional climate model simulations of seasonal precipitation over Europe, Clim. Dynam., 35, 685-711, doi:10.1007/s00382-009-0607-7, 2010.

Reid, P., Hari, R., Beaugrand, G., Livingstone, D., Marty, C., Straile, D., Barichivich, J., Goberville, E., Adrian, R., Aono, Y., Brown, R., Foster, J., Groisman, P., Hélaou et, P., Hsu, H.-H., Kirby, R., Knight, J., Kraberg, A., Li, J., Lo, T.-T., Myneni, R., North, R., Pounds, J., Sparks, T., St ubi, R., Tian, Y., Wiltshire, K., Xiao, D., and Zhu, Z.: Global impacts of the 1980s regime shift, Glob. Change Biol., 22, 682-703, doi:10.1111/gcb.13106, 2015.

Rousselot, M., Durand, Y., Giraud, G., Mérindol, L., Dombrowski-Etchevers, I., Déqué, M., and Castebrunet, H.: Statistical adaptation of ALADIN RCM outputs over the French Alps -application to future climate and snow cover, The Cryosphere, 6, 785-805, doi:10.5194/tc-6-785-2012, 2012.

Saccone, P., Morin, S., Colomb, C., Baptist, F., Bonneville, J.-M., Colace, M.-P., Domine, F., Faure, M., Geremia, R., Lochet, J., Poly, F., Lavorel, S., and Clement, J.-C.: The effects of snowpack properties and plant strategies on litter decomposition during winter in subalpine meadows, Plant and Soil, 363, 215-229, doi:10.1007/s11104-012-1307-3, 2013.

Schmucki, E., Marty, C., Fierz, C., and Lehning, M.: Simulations of 21st century snow response to climate change in Switzerland from a set of RCMs, Int. J. Climatol., doi:10.1002/joc.4205, 2014. 
Geosci. Model Dev. Discuss., doi:10.5194/gmd-2016-168, 2016

Manuscript under review for journal Geosci. Model Dev.

Published: 29 September 2016

(c) Author(s) 2016. CC-BY 3.0 License.

Spandre, P., Morin, S., Lafaysse, M., George-Marcelpoil, E., Francois, H., and Lejeune, Y.: Integration of snow management in a detailed snowpack model, Cold Regions Science and Technology, doi:10.1016/j.coldregions.2016.01.002, 2016.

Sterl, A.: On the (in) homogeneity of reanalysis products, J. Climate, 17, 3866-3873, doi:http://dx.doi.org/10.1175/1520-0442(2004)017<3866:OTIORP>2.0.CO;2, 2004.

Teutschbein, C. and Seibert, J.: Bias correction of regional climate model simulations for hydrological climate-change impact studies: Review and evaluation of different methods, J. Hydrol., 456, 12-29, doi:10.1016/j.jhydrol.2012.05.052, 2012.

Teutschbein, C. and Seibert, J.: Is bias correction of regional climate model (RCM) simulations possible for non-stationary conditions?, Hydrol. Earth Syst. Sc., 17, 5061-5077, doi:10.5194/hess-17-5061-2013, 2013.

Themeß1, M. J., Gobiet, A., and Leuprecht, A.: Empirical-statistical downscaling and error correction of daily precipitation from regional climate models, Int. J. Climatol., 31, 1530-1544, doi:10.1002/joc.2168, 2011.

Themeß1, M. J., Gobiet, A., and Heinrich, G.: Empirical-statistical downscaling and error correction of regional climate models and its impact on the climate change signal, Climatic Change, 112, 449-468, doi:10.1007/s10584-011-0224-4, 2012.

Thuiller, W., Guéguen, M., Georges, D., Bonet, R., Chalmandrier, L., Garraud, L., Renaud, J., Roquet, C., Van Es, J., Zimmermann, N., and Lavergne, S.: Are different facets of plant diversity well protected against climate and land cover changes? A test study in the French Alps, Ecography, 37, 1254-1266, doi:10.1111/ecog.00670, 2014

Uppala, S. M., KÅllberg, P. W., Simmons, A. J., Andrae, U., Bechtold, V. D. C., Fiorino, M., Gibson, J. K., Haseler, J., Hernandez, A., Kelly, G. A., Li, X., Onogi, K., Saarinen, S., Sokka, N., Allan, R. P., Andersson, E., Arpe, K., Balmaseda, M. A., Beljaars, A. C. M., Berg, L. V. D., Bidlot, J., Bormann, N., Caires, S., Chevallier, F., Dethof, A., Dragosavac, M., Fisher, M., Fuentes, M., Hagemann, S., Hólm, E., Hoskins, B. J., Isaksen, L., Janssen, P. A. E. M., Jenne, R., Mcnally, A. P., Mahfouf, J.-F., Morcrette, J.-J., Rayner, N. A., Saunders, R. W., Simon, P., Sterl, A., Trenberth, K. E., Untch, A., Vasiljevic, D., Viterbo, P., and Woollen, J.: The ERA-40 re-analysis, Quarterly Journal of the Royal Meteorological Society, 131, 29613012, doi:10.1256/qj.04.176, 2005

Vidal, J.-P., Martin, E., Franchisty, L., Baillon, M., and Soubeyroux, J.-M.: A 50 year high resolution atmospheric reanalysis over France with the Safran system, International Journal of Climatology, 30, 1627-1644, 2010.

Vionnet, V., Brun, E., Morin, S., Boone, A., Martin, E., Faroux, S., Moigne, P. L., and Willemet, J.-M.: The detailed snowpack scheme Crocus and its implementation in SURFEX v7.2, Geosci. Model. Dev., 5, 773791, doi:10.5194/gmd-5-773-2012, 2012.

Vrac, M., Stein, M., and Hayhoe, K.: Statistical downscaling of precipitation through nonhomogeneous stochastic weather typing, Clim. Res., 34, 169, doi:doi: 10.3354/cr00696, 2007a.

Vrac, M., Stein, M., Hayhoe, K., and Liang, X.-Z.: A general method for validating statistical downscaling methods under future climate change, Geophys. Res. Lett., 34, doi:10.1029/2007GL030295, 2007b.

Vrac, M., Drobinski, P., Merlo, A., Herrmann, M., Lavaysse, C., Li, L., and Somot, S.: Dynamical and statistical downscaling of the French Mediterranean climate: uncertainty assessment, Nat. Hazard. Earth Sys., 12, 2769-2784, doi:10.5194/nhess-12-2769-2012, 2012. 
Geosci. Model Dev. Discuss., doi:10.5194/gmd-2016-168, 2016

Manuscript under review for journal Geosci. Model Dev.

Published: 29 September 2016

(c) Author(s) 2016. CC-BY 3.0 License.

Wilby, R., Wigley, T., Conway, D., Jones, P., Hewitson, B., Main, J., and Wilks, D.: Statistical downscal-

910 ing of general circulation model output: a comparison of methods, Water Resour. Res., 34, 2995-3008, doi:10.1029/98WR02577, 1998. 
Geosci. Model Dev. Discuss., doi:10.5194/gmd-2016-168, 2016

Manuscript under review for journal Geosci. Model Dev.

Published: 29 September 2016

(c) Author(s) 2016. CC-BY 3.0 License.

Table 1. Variables considered in this study : Variable name, Abbreviation, Input or Output of Crocus, Units, Level and Method of integration (SAFRAN from hourly to daily) and disaggregation (ALADIN adjusted data from daily to hourly). Variables used for the evaluation of the ADAMONT method are highlighted in bold characters. SW = shortwave, $\mathrm{LW}=$ longwave.

\begin{tabular}{llllll}
\hline Variable & Abbreviation & Input/Output & Units & Level & Method \\
\hline Temperature & Tair & Input & $\mathrm{K}$ & $2 \mathrm{~m}$ & Min, max \\
Specific Humidity & Qair & Input & $\mathrm{kg} \mathrm{kg}^{-1}$ & $2 \mathrm{~m}$ & Last value \\
Wind speed & Wind & Input & $\mathrm{m} \mathrm{s}^{-1}$ & $10 \mathrm{~m}$ & Last value \\
Rainfall Rate & Rainf & Input & $\mathrm{kg} \mathrm{m}^{-2} \mathrm{~h}^{-1}$ & Surface & Mean \\
Snowfall Rate & Snowf & Input & $\mathrm{kg} \mathrm{m}^{-2} \mathrm{~h}^{-1}$ & Surface & Mean \\
Incident LW Radiation & LWdown & Input & $\mathrm{W} \mathrm{m}^{-2}$ & Surface & Mean \\
Incident Direct SW Radiation & DIR_SWdown & Input & $\mathrm{W} \mathrm{m}^{-2}$ & Surface & Mean \\
Incident Diffuse SW Radiation & SCA_SWdown & Input & $\mathrm{W} \mathrm{m}^{-2}$ & Surface & Mean \\
Snowpack Depth & SNOWDEPTH & Output & $\mathrm{m}$ & $<$ Surface & - \\
\hline
\end{tabular}


Geosci. Model Dev. Discuss., doi:10.5194/gmd-2016-168, 2016

Manuscript under review for journal Geosci. Model Dev.

Published: 29 September 2016

(c) Author(s) 2016. CC-BY 3.0 License.

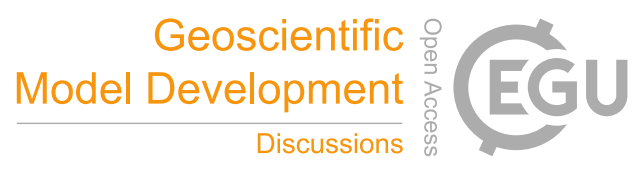

(c) (1)

Table 2. Name and description of the different configurations used in the evaluation of the ADAMONT method.

\begin{tabular}{ll}
\hline Name & Description \\
\hline SAFRAN reanalysis & $\begin{array}{l}\text { Simulation carried out with the SAFRAN reanalysis, over the period } \\
\text { considered }\end{array}$ \\
RCM L. 1980-1995 & $\begin{array}{l}\text { Simulation carried out over the period considered, with the ALADIN } \\
\text { RCM, and the learning period 1980-1995 }\end{array}$ \\
RCM L. 1980-1995 N50 & $\begin{array}{l}\text { Simulation carried out over the period considered, with the ALADIN } \\
\text { RCM, and the learning period 1980-1995, using the spatial and altitudi- } \\
\text { nal RCM grid points neighbour selection technique (N=50) } \\
\text { RCM L. 1980-1995 no corr }\end{array}$ \\
Same as RCM APPR 1980-1995, but without performing the last quan- \\
tile mapping for rain and snow \\
Simulation carried out over the period considered, with the ALADIN \\
RCM, and the learning period 1995-2010 \\
Simulation carried out over the period considered, with the ALADIN \\
RCM, and the learning period 1995-2010, using the spatial and altitudi- \\
nal RCM grid points neighbour selection technique (N=50) \\
Same as RCM APPR 1995-2010, but without performing the last quan- \\
tile mapping for rain and snow \\
Simulation carried out over the period considered, with the ALADIN \\
RCM, and the learning period 1980-2010 \\
Simulation carried out over the period considered, with the ALADIN \\
RCM, and the learning period 1980-2010, using the spatial and altitudi- \\
nal RCM grid points neighbour selection technique (N=50) \\
Same as RCM APPR 1980-2010, but without performing the last quan- \\
tile mapping for rain and snow
\end{tabular}


Geosci. Model Dev. Discuss., doi:10.5194/gmd-2016-168, 2016 Manuscript under review for journal Geosci. Model Dev.

Published: 29 September 2016

(c) Author(s) 2016. CC-BY 3.0 License.

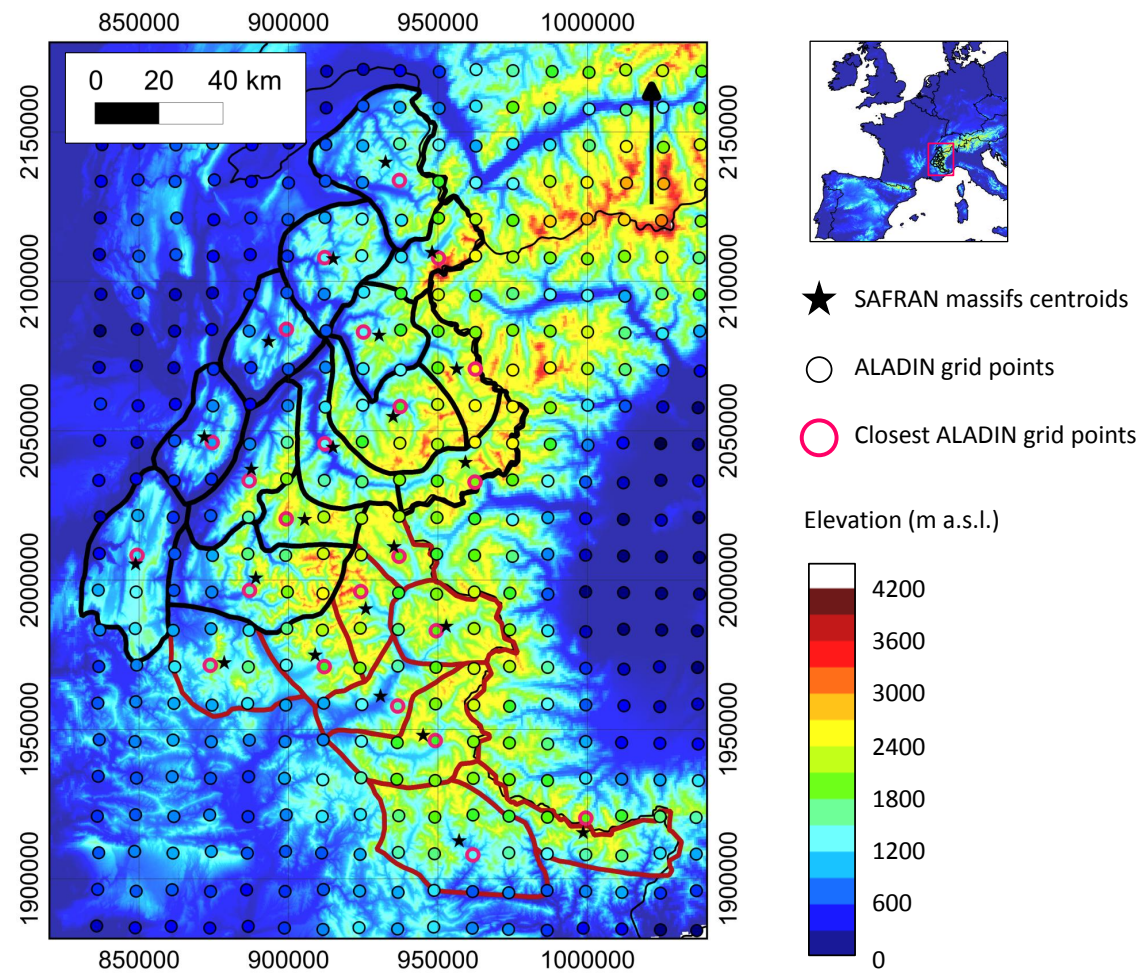

Figure 1. Description of the study site and the geometry and elevation of the SAFRAN reanalysis and the ALADIN RCM. The top right panel illustrates the spatial domain (FRB12) covered by the simulation, and the location of our study site is indicated by the pink box. In the main panel, SAFRAN massifs are delimited by the black contours for the Northern Alps and by the burgundy contours for the Southern Alps, and their centroids are indicated by the black stars. ALADIN grid points are represented by dots, with pink contour for the grid points closest to each SAFRAN massif centroid. Surface elevation of the SAFRAN reanalysis (50m-DEM from the Institut National d'Information Géographique et Forestière (IGN)) in France and from GTOPO30 (resolution of 30 arc seconds $\approx 1 \mathrm{~km}$ ) outside of France, as well as the elevation of ALADIN is indicated by the color palette (in $\mathrm{m}$ above sea level (a.s.l.)). Projection is in Lambert II étendu (L2E). 
Geosci. Model Dev. Discuss., doi:10.5194/gmd-2016-168, 2016

Manuscript under review for journal Geosci. Model Dev.

Published: 29 September 2016

(c) Author(s) 2016. CC-BY 3.0 License.

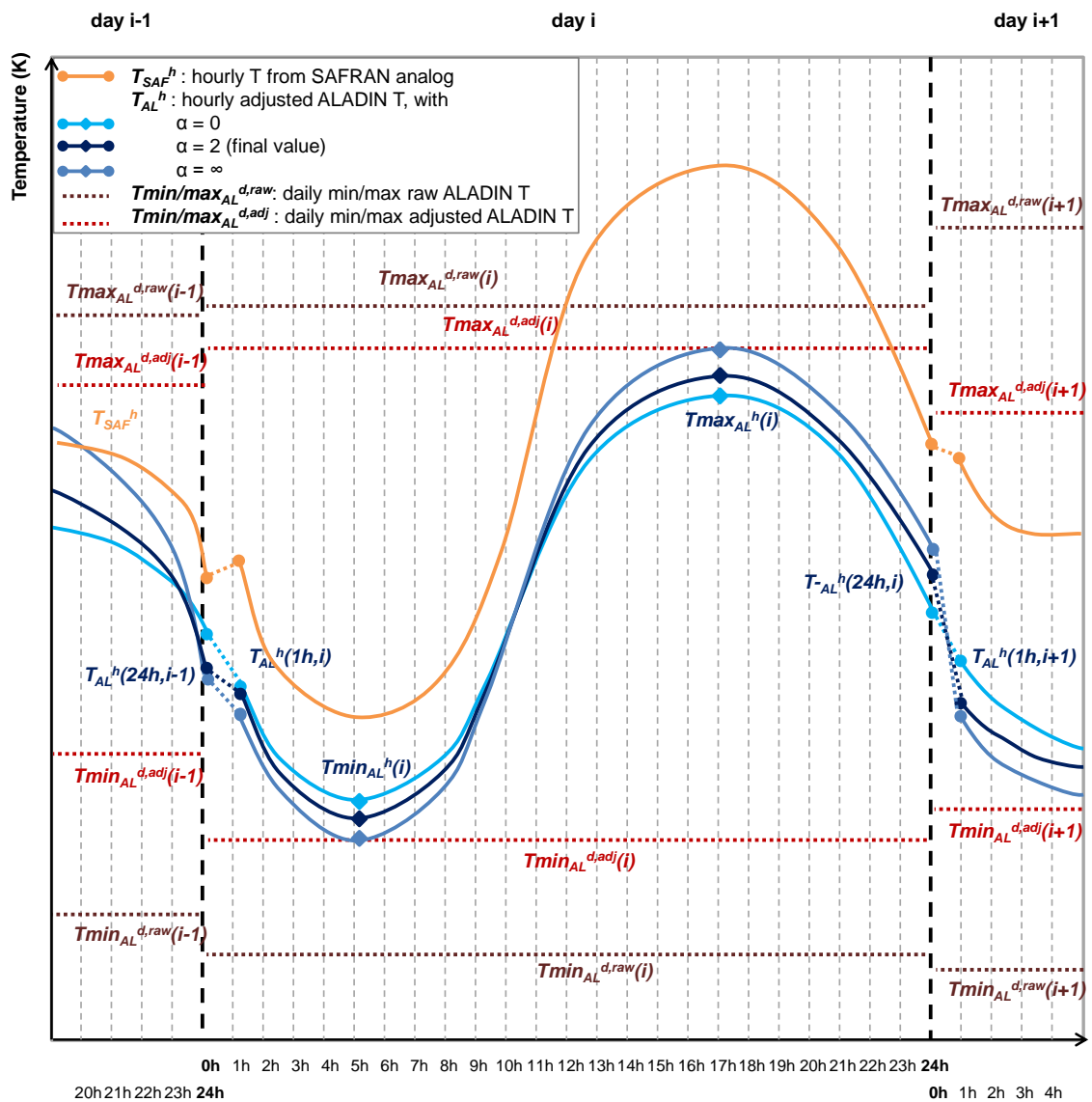

Figure 2. Illustration of the different parameters taken into account in the disaggregation of ALADIN temperature from a daily integration period into an hourly time step. $T_{A L}^{h}(1 h, i)$ and $T_{A L}^{h}(24 h, i-1)$ are the hourly adjusted ALADIN temperature values at the first time step of day $i$ and at the last time step of the day before (i-1), $\operatorname{Tmin}_{A L}^{h}(i)$ and $\operatorname{Tmax}_{A L}^{h}(i)$ are the hourly minimum and maximum adjusted ALADIN temperature values respectively, and $\operatorname{Tmin}_{A L}^{d, a d j}(i)$ and $\operatorname{Tmax}_{A L}^{d, a d j}(i)$ are the daily minimum and maximum adjusted ALADIN temperature values respectively. $\alpha$ is a parameter which can be tuned to give more importance to the minimisation of differences between daily and hourly ALADIN minima and maxima. Hourly adjusted ALADIN temperature time series for values of $\alpha$ of zero, 2 and infinite are shown. $T_{S A F}^{h}$ corresponds to the hourly series of the chosen daily analogue, and $\operatorname{Tmin}_{A L}^{d, r a w}(i)$ and $\operatorname{Tmax}_{A L}^{d, \text { raw }}(i)$ are the daily raw minimum and maximum ALADIN temperature values (before adjustment). 
Geosci. Model Dev. Discuss., doi:10.5194/gmd-2016-168, 2016

Manuscript under review for journal Geosci. Model Dev.

Published: 29 September 2016

(c) Author(s) 2016. CC-BY 3.0 License.

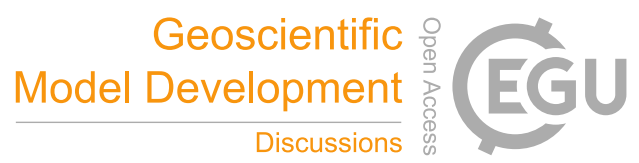

(c) (1)
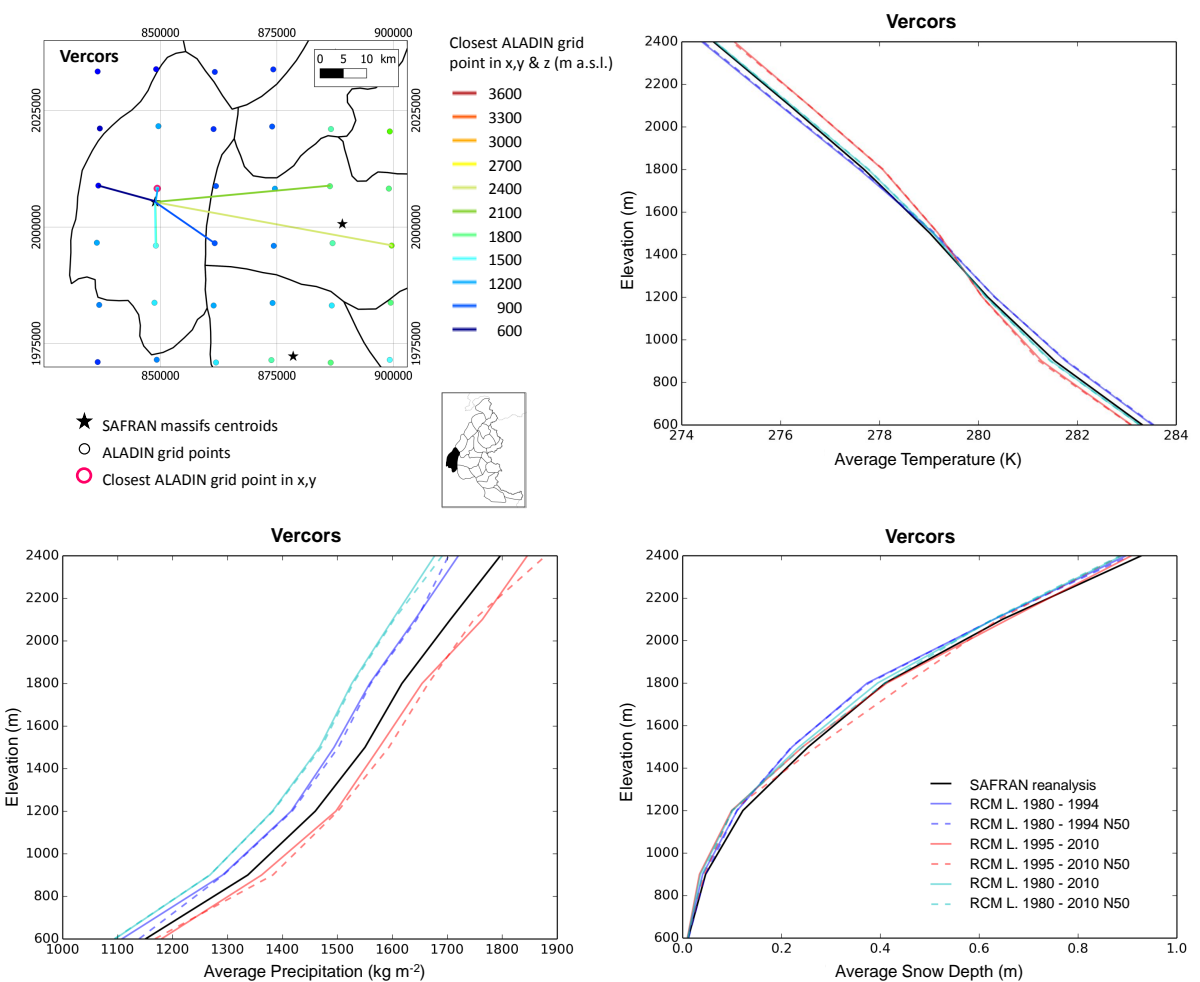

Figure 3. (top left) Location of the Vercors massif, with ALADIN grid points chosen as the closest in $x, y$ (pink contour) and in $\mathrm{x}, \mathrm{y}$ and $\mathrm{z}$ (coloured lines linking each SAFRAN massif centroid with the corresponding grid point in ALADIN for the different elevations considered (in $m$ above sea level (a.s.l.))). (top right) Mean temperature altitudinal gradient over 1979-2010 in each adjusted RCM simulation (different learning periods and 2 neighbour selection methods) and in SAFRAN. (bottom left) Mean precipitation altitudinal gradient over 1979-2010. (bottom right) Mean snow depth altitudinal gradient over 1979-2010. 
Geosci. Model Dev. Discuss., doi:10.5194/gmd-2016-168, 2016

Manuscript under review for journal Geosci. Model Dev.

Published: 29 September 2016

(c) Author(s) 2016. CC-BY 3.0 License.

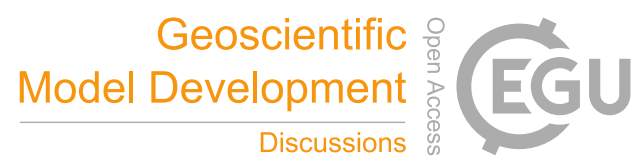

(c) (1)
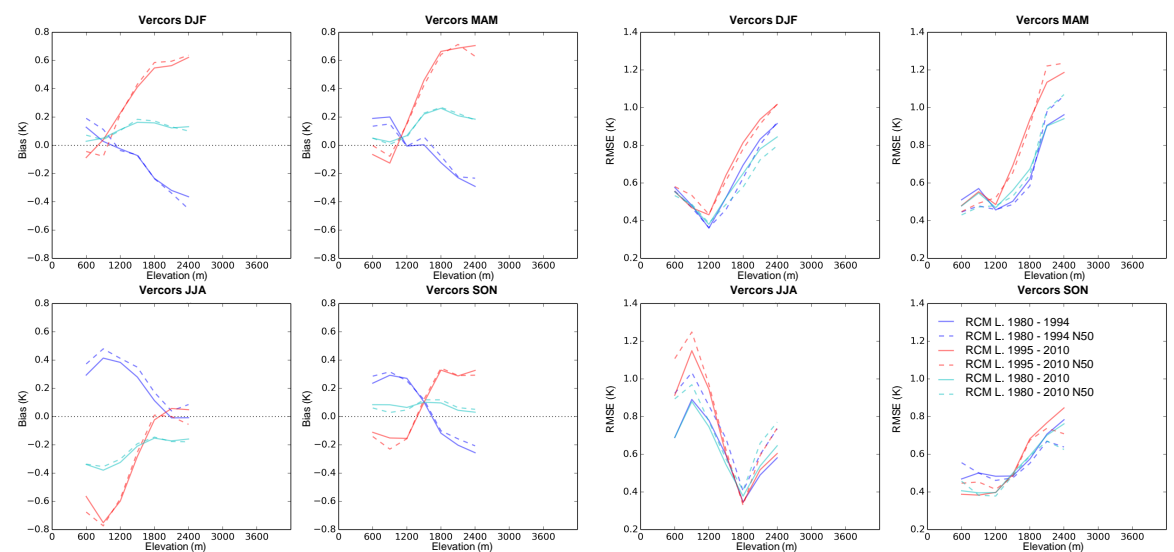

Figure 4. Temperature mean bias and root mean square error (RMSE) of each adjusted RCM simulation compared to SAFRAN over the period 1979-2010 for the Vercors massif as a function of elevation.
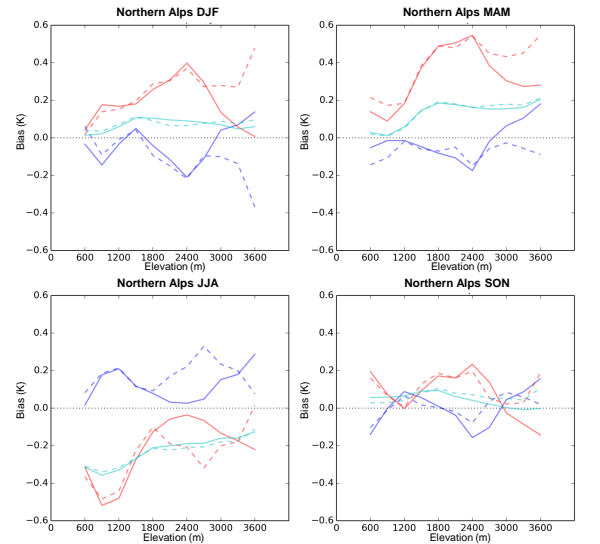

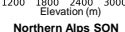

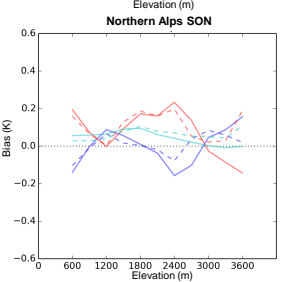

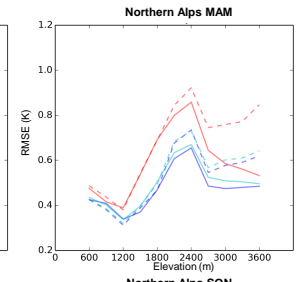

Elevation (m)
Northern Alps SON

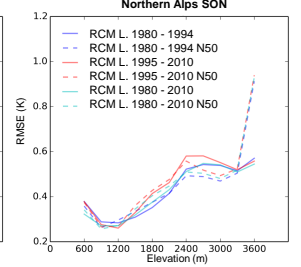

Figure 5. Temperature mean bias and root mean square error of each adjusted RCM simulation compared to SAFRAN over the period 1979-2010 for the Northern Alps as a function of elevation. 
Geosci. Model Dev. Discuss., doi:10.5194/gmd-2016-168, 2016

Manuscript under review for journal Geosci. Model Dev.

Published: 29 September 2016

(c) Author(s) 2016. CC-BY 3.0 License.

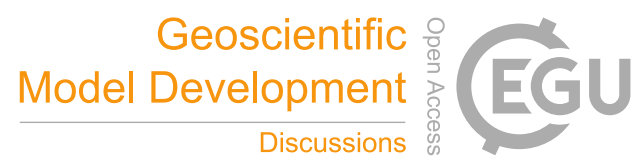

(c) (1)
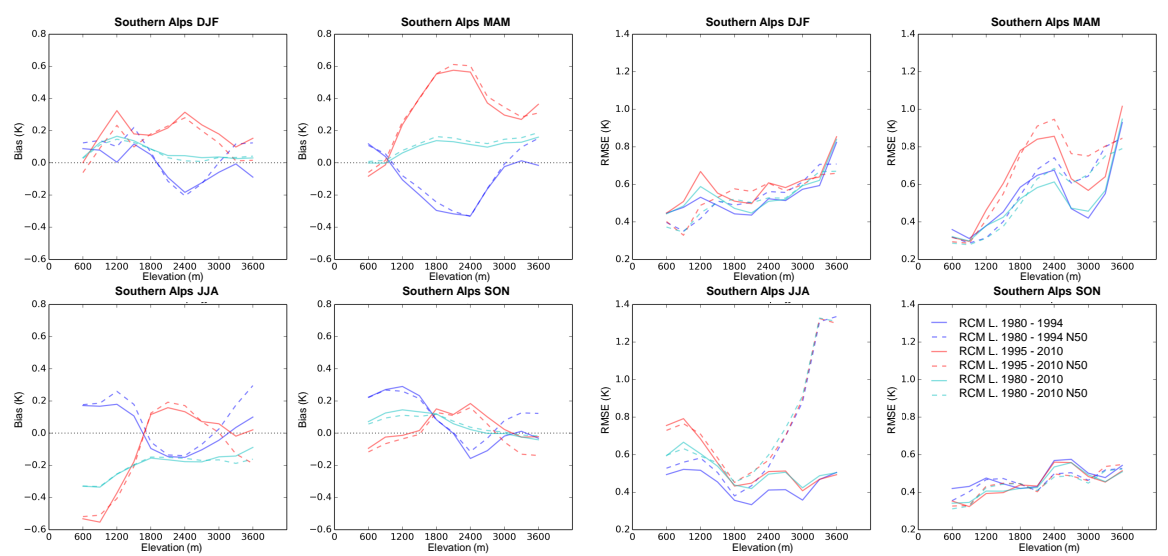

Figure 6. Temperature mean bias and root mean square error of each adjusted RCM simulation compared to SAFRAN over the period 1979-2010 for the Southern Alps as a function of elevation.
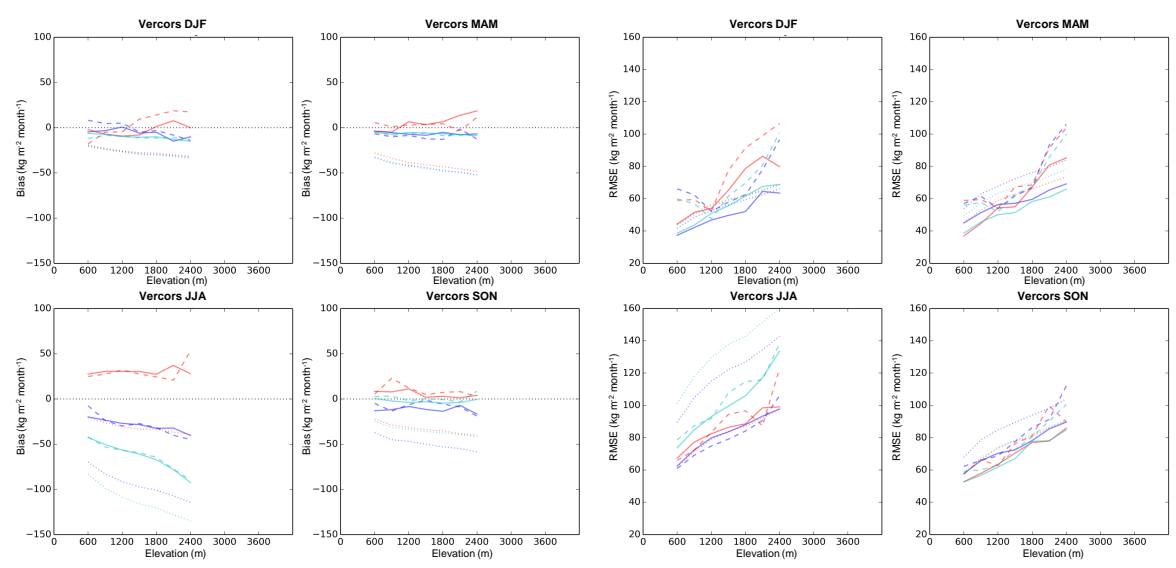

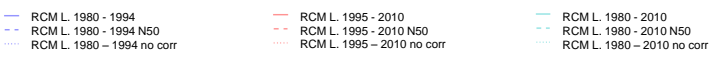

Figure 7. Precipitation mean bias and root mean square error (RMSE) of each adjusted RCM simulation compared to SAFRAN over the period 1979-2010 for the Vercors massif as a function of elevation. 
Geosci. Model Dev. Discuss., doi:10.5194/gmd-2016-168, 2016

Manuscript under review for journal Geosci. Model Dev.

Published: 29 September 2016

(c) Author(s) 2016. CC-BY 3.0 License.

(c) (i)
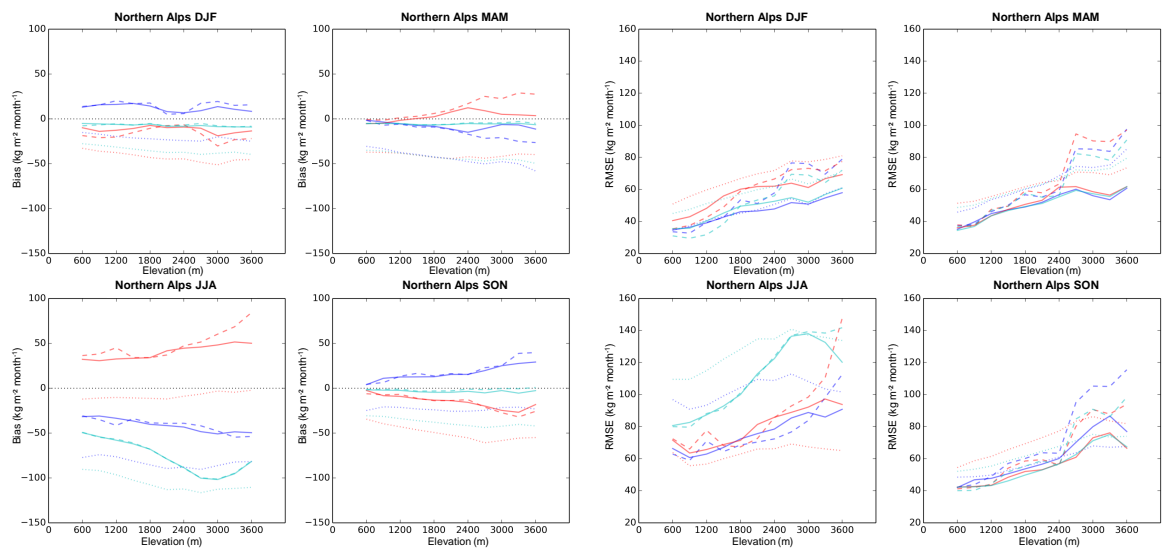

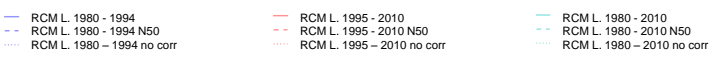

Figure 8. Precipitation mean bias and root mean square error of each adjusted RCM simulation compared to SAFRAN over the period 1979-2010 for the Northern Alps as a function of elevation.
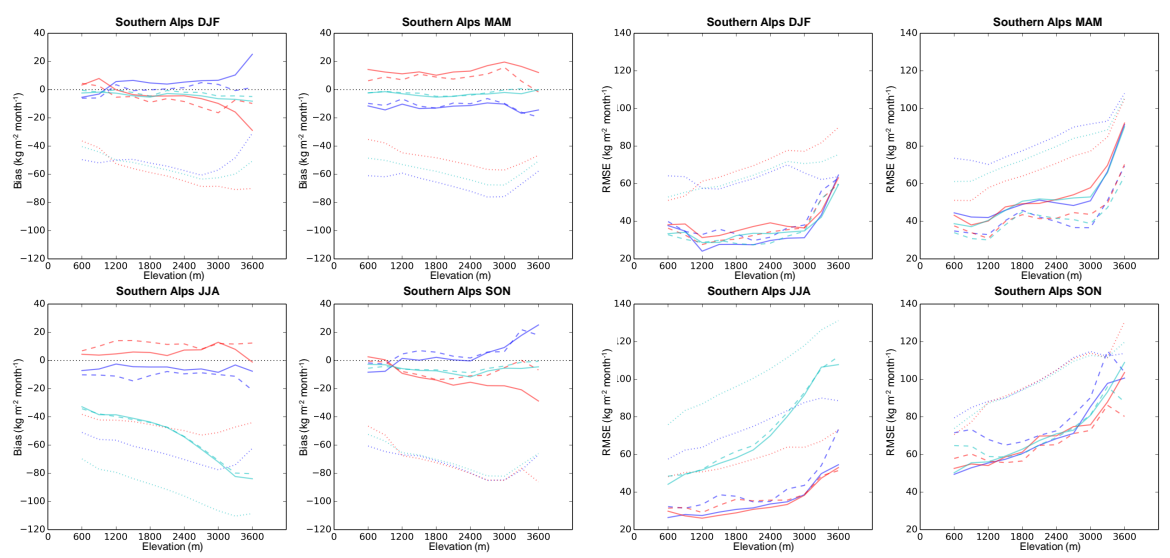

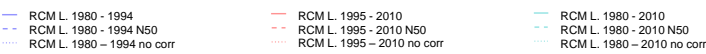

Figure 9. Precipitation mean bias and root mean square error of each adjusted RCM simulation compared to SAFRAN over the period 1979-2010 for the Southern Alps as a function of elevation. 
Geosci. Model Dev. Discuss., doi:10.5194/gmd-2016-168, 2016

Manuscript under review for journal Geosci. Model Dev.

Published: 29 September 2016

(c) Author(s) 2016. CC-BY 3.0 License.

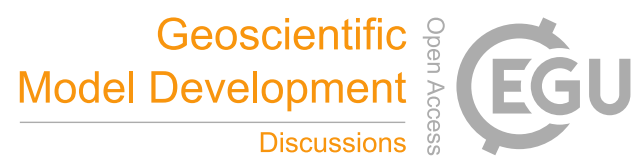

(c) (i)
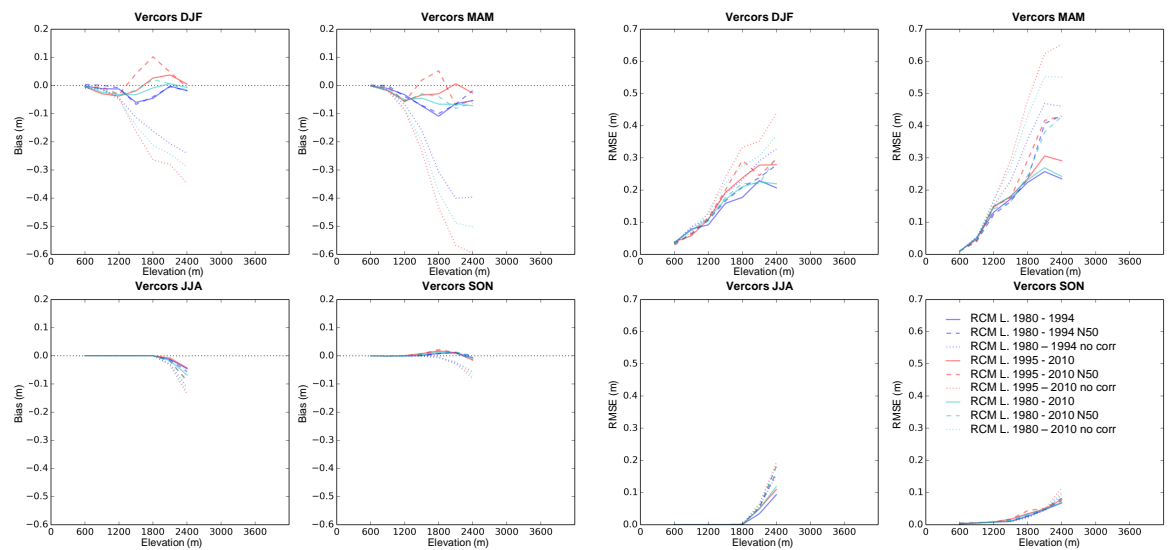

Figure 10. Snow depth mean bias and root mean square error (RMSE) of each adjusted RCM simulation compared to SAFRAN over the period 1979-2010 for the Vercors massif as a function of elevation.
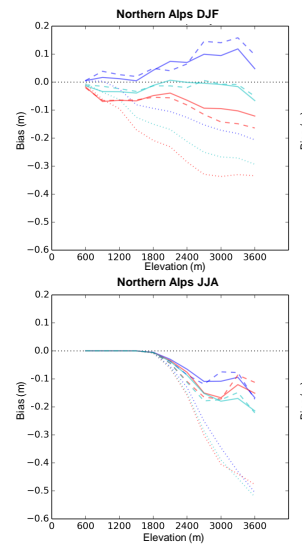

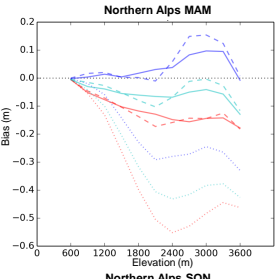

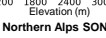

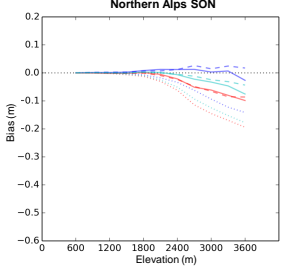

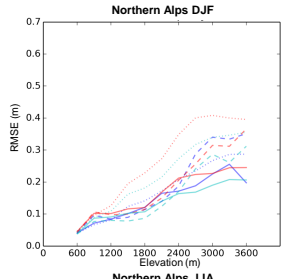

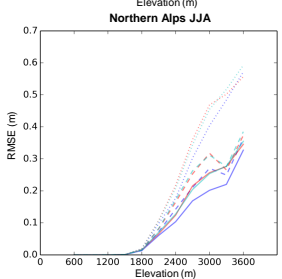

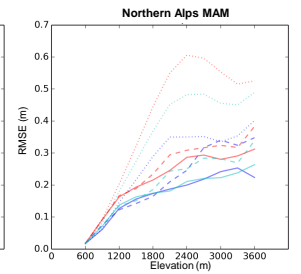

Northern Alps SoN

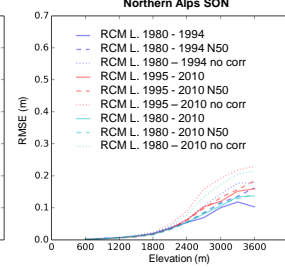

Figure 11. Snow depth mean bias and root mean square error of each adjusted RCM simulation compared to SAFRAN over the period 1979-2010 for the Northern Alps as a function of elevation. 
Geosci. Model Dev. Discuss., doi:10.5194/gmd-2016-168, 2016

Manuscript under review for journal Geosci. Model Dev.

Published: 29 September 2016

(c) Author(s) 2016. CC-BY 3.0 License.

(c) (i)
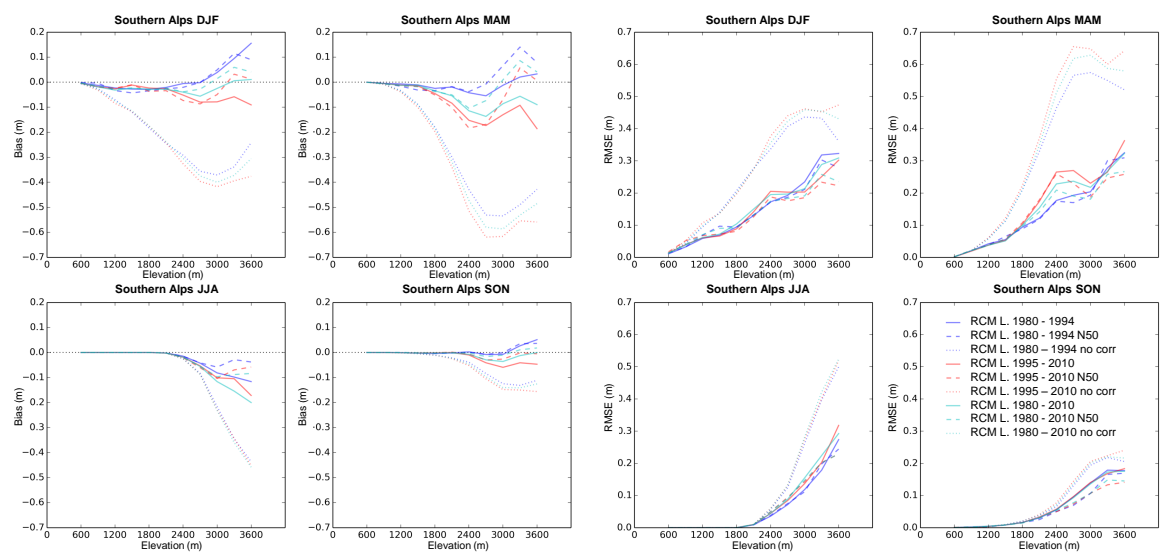

Figure 12. Snow depth mean bias and root mean square error of each adjusted RCM simulation compared to SAFRAN over the period 1979-2010 for the Southern Alps as a function of elevation. 
Geosci. Model Dev. Discuss., doi:10.5194/gmd-2016-168, 2016

Manuscript under review for journal Geosci. Model Dev.

Published: 29 September 2016

(c) Author(s) 2016. CC-BY 3.0 License.

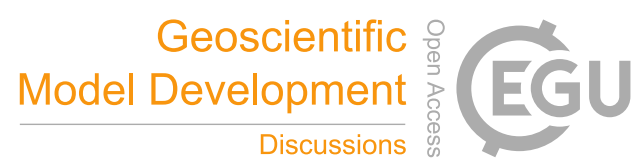

(c) (i)
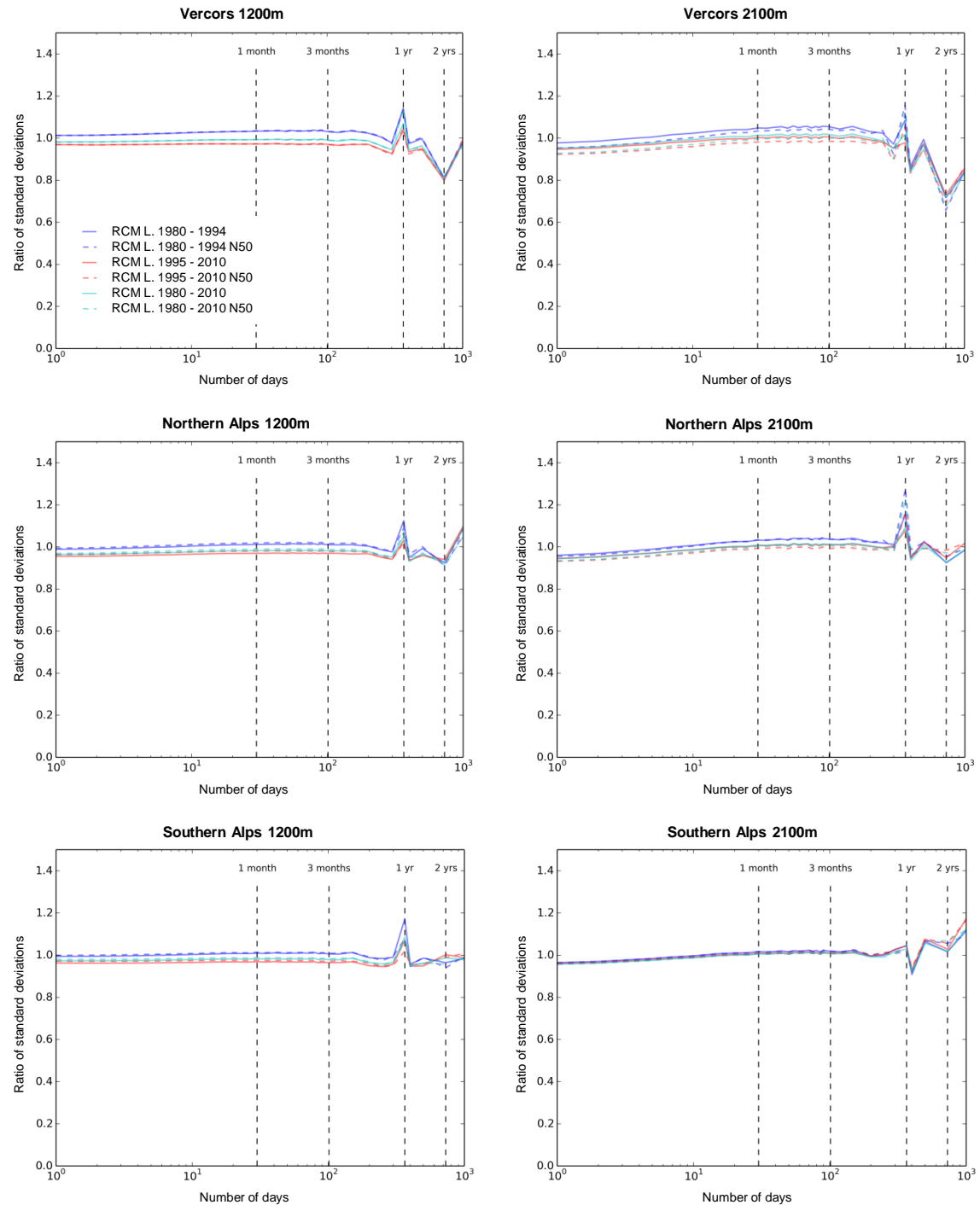

Figure 13. Ratio of standard deviations between SAFRAN and adjusted RCM temperature as a function of the integration time over the period 1979-2010, for the Vercors massif, the Northern and Southern Alps, and at $1200 \mathrm{~m}$ a.s.l. and $2100 \mathrm{~m}$ a.s.l.. 
Geosci. Model Dev. Discuss., doi:10.5194/gmd-2016-168, 2016

Manuscript under review for journal Geosci. Model Dev.

Published: 29 September 2016

(c) Author(s) 2016. CC-BY 3.0 License.

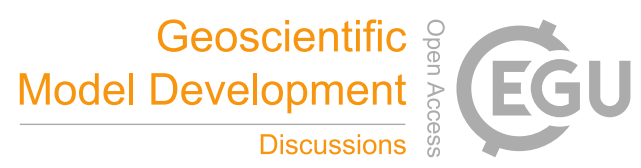

(c) (i)
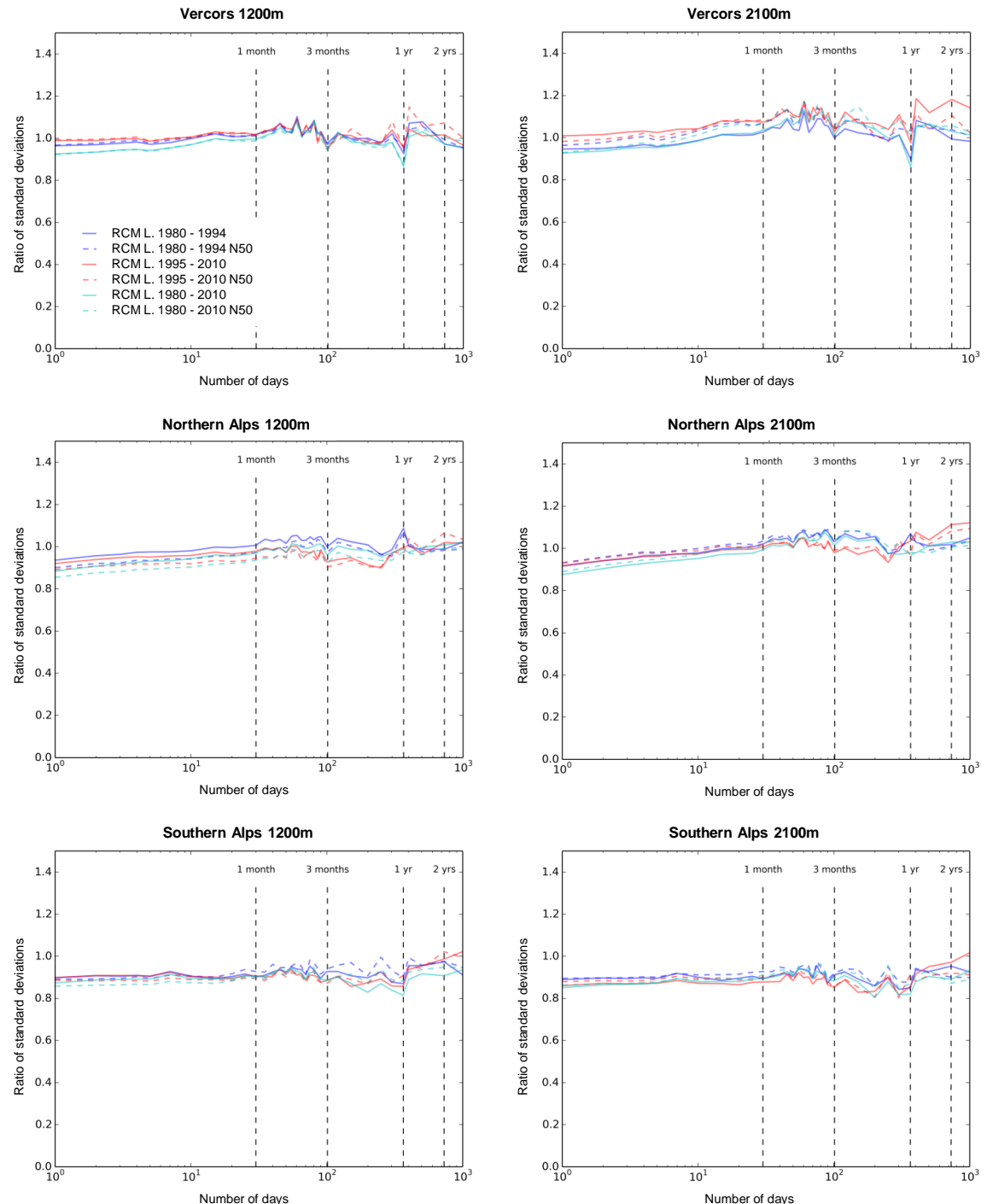

Figure 14. Ratio of standard deviations between SAFRAN and adjusted RCM precipitation as a function of the integration time over the period 1979-2010, for the Vercors massif, the Northern and Southern Alps, and at $1200 \mathrm{~m}$ a.s.l. and $2100 \mathrm{~m}$ a.s.l.. 
Geosci. Model Dev. Discuss., doi:10.5194/gmd-2016-168, 2016

Manuscript under review for journal Geosci. Model Dev.

Published: 29 September 2016

(c) Author(s) 2016. CC-BY 3.0 License.

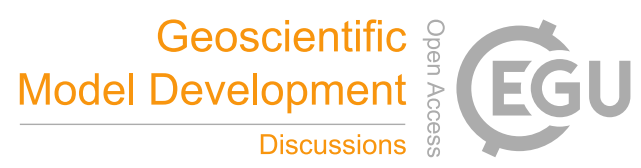

(c) (i)
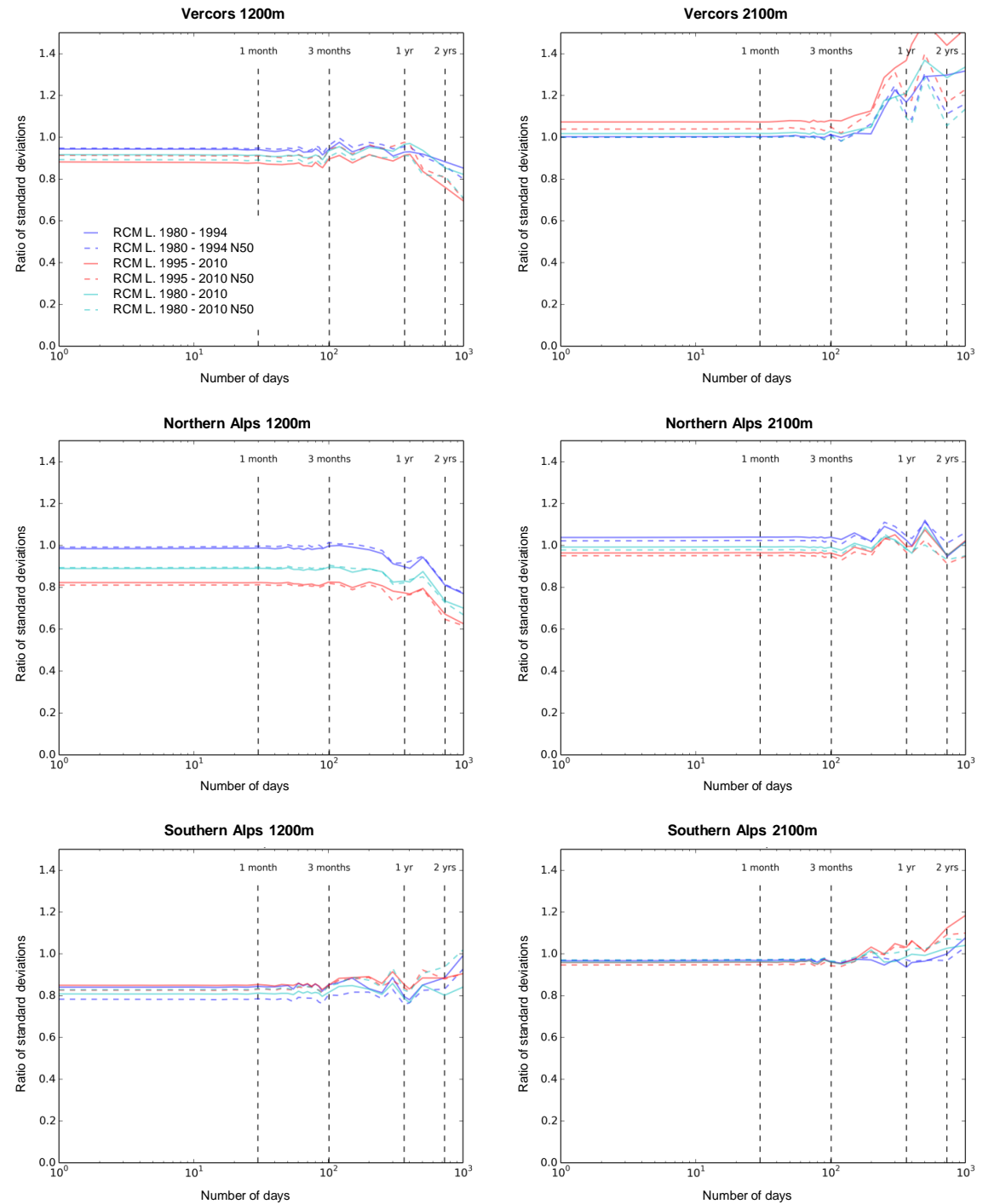

Figure 15. Ratio of standard deviations between SAFRAN and adjusted RCM snow depth as a function of the integration time over the period 1979-2010, for the Vercors massif, the Northern and Southern Alps, and at $1200 \mathrm{~m}$ a.s.l. and $2100 \mathrm{~m}$ a.s.l.. 
Geosci. Model Dev. Discuss., doi:10.5194/gmd-2016-168, 2016

Manuscript under review for journal Geosci. Model Dev.

Published: 29 September 2016

(c) Author(s) 2016. CC-BY 3.0 License.
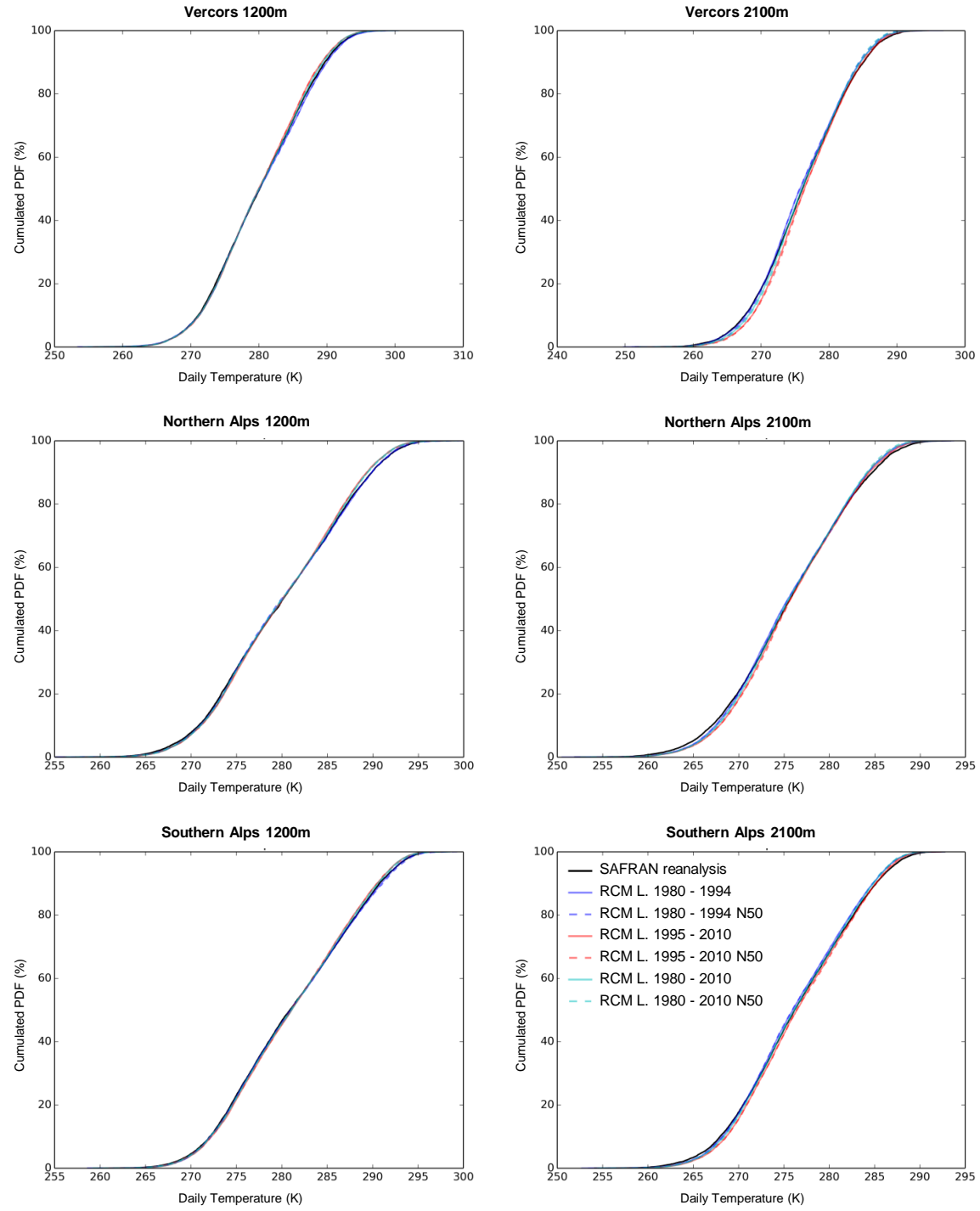

Figure 16. Cumulated probability density function (PDF) of daily temperature in each adjusted RCM simulation and in SAFRAN over 1979-2010, for the Vercors massif, the Northern and Southern Alps, and at $1200 \mathrm{~m}$ a.s.l. and $2100 \mathrm{~m}$ a.s.1.. 
Geosci. Model Dev. Discuss., doi:10.5194/gmd-2016-168, 2016

Manuscript under review for journal Geosci. Model Dev.

Published: 29 September 2016

(c) Author(s) 2016. CC-BY 3.0 License.
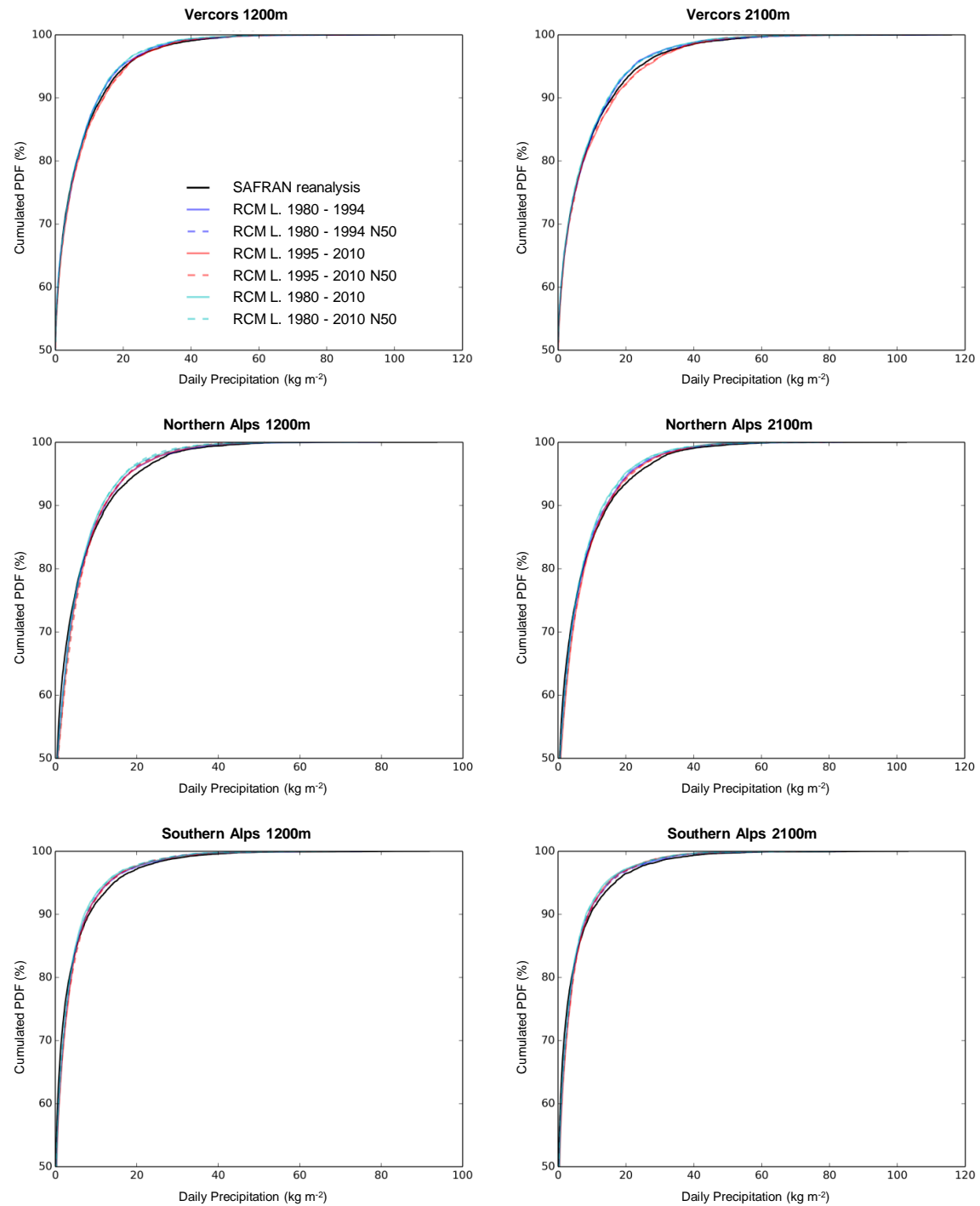

Figure 17. Cumulated probability density function (PDF) of daily precipitation in each adjusted RCM simulation and in SAFRAN over 1979-2010, for the Vercors massif, the Northern and Southern Alps, and at $1200 \mathrm{~m}$ a.s.l. and $2100 \mathrm{~m}$ a.s.l.. 
Geosci. Model Dev. Discuss., doi:10.5194/gmd-2016-168, 2016

Manuscript under review for journal Geosci. Model Dev.

Published: 29 September 2016

(c) Author(s) 2016. CC-BY 3.0 License.
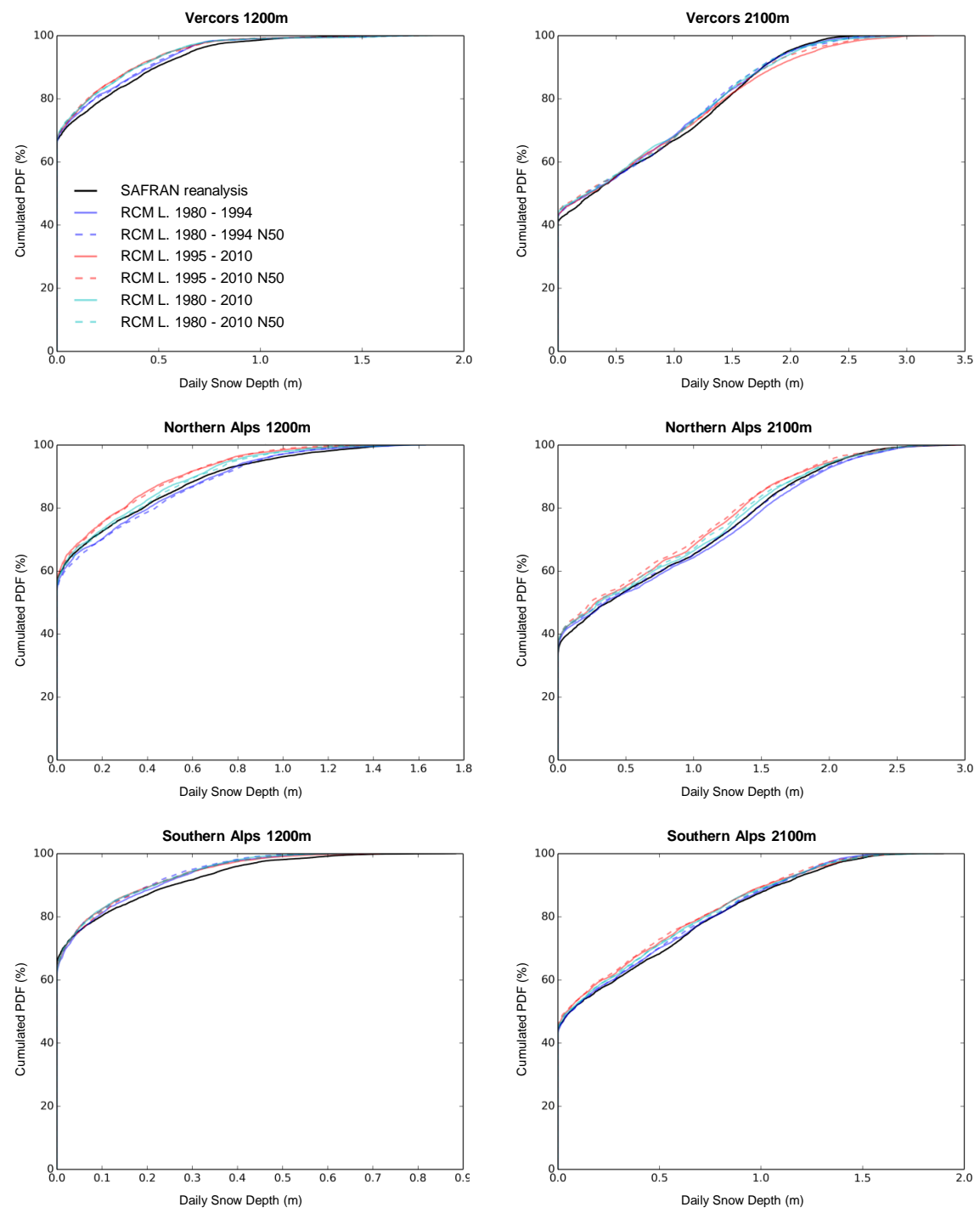

Figure 18. Cumulated probability density function (PDF) of daily snow depth in each adjusted RCM simulation and in SAFRAN over 1979-2010, for the Vercors massif, the Northern and Southern Alps, and at $1200 \mathrm{~m}$ a.s.l. and $2100 \mathrm{~m}$ a.s.1.. 
Geosci. Model Dev. Discuss., doi:10.5194/gmd-2016-168, 2016

Manuscript under review for journal Geosci. Model Dev.

Published: 29 September 2016

(c) Author(s) 2016. CC-BY 3.0 License.

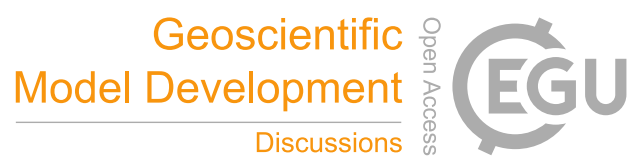

(c) (i)
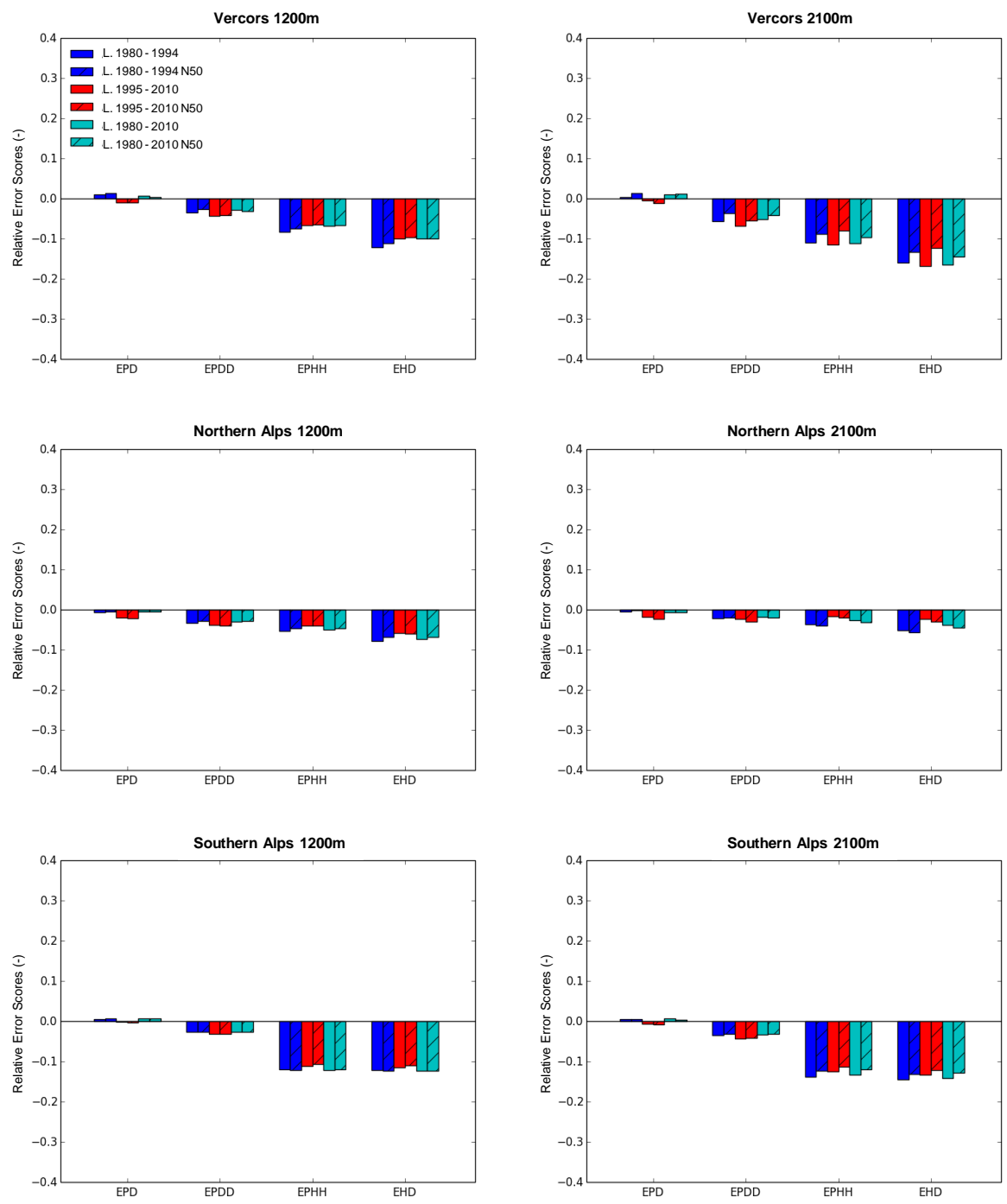

Figure 19. Scores for the duration and persistence of precipitation events in each adjusted RCM simulation compared to SAFRAN over 1979-2010, for the Vercors massif, the Northern and Southern Alps, and at 1200 $\mathrm{m}$ a.s.l. and $2100 \mathrm{~m}$ a.s.l.. EPD = relative error on the probability of a dry day, EPDD = relative error on the probability of a dry day following a dry day, EPHH = relative error on the probability of a wet day following a wet day, $\mathrm{EHD}=$ relative error on the mean duration of wet periods. 
Geosci. Model Dev. Discuss., doi:10.5194/gmd-2016-168, 2016

Manuscript under review for journal Geosci. Model Dev.

Published: 29 September 2016

(c) Author(s) 2016. CC-BY 3.0 License.

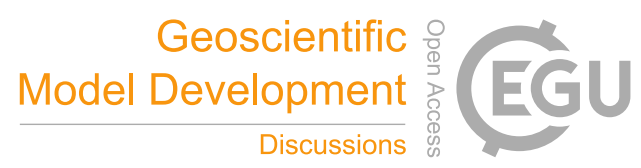

(c) (i)
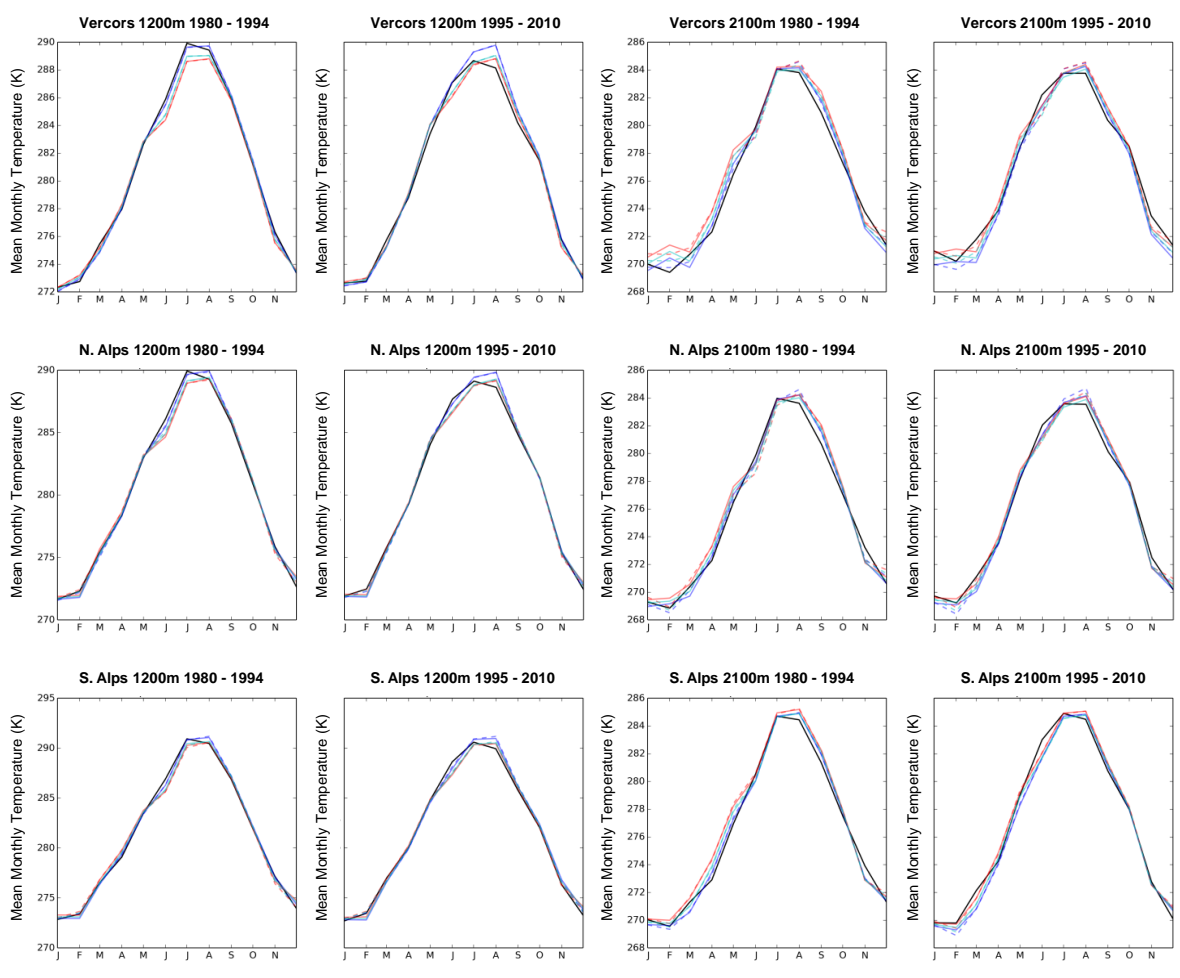

$\begin{array}{ll}\text { - } & \text { SAFRAN reanalysis } \\ \text { - } & \text { RCM L. } 1980-1994 \\ \text { - } & \text { RCM L. } 1980-1994 \text { N50 }\end{array}$

- RCM L. $1995-2010$

- - RCM L. 1995 - 2010 N50

$\begin{array}{ll}\text { _ } & \text { RCM L. } 1980-2010 \\ \text { __ } & \text { RCM L. } 1980-2010 \text { N5 }\end{array}$

Figure 20. Mean annual cycle of temperature in each adjusted RCM simulation and in SAFRAN over the period 1980-1994 and 1995-2010, for the Vercors massif, the Northern and Southern Alps, and at $1200 \mathrm{~m}$ a.s.l. and $2100 \mathrm{~m}$ a.s.l.. Letters on the $\mathrm{x}$-axis correspond to the different months of the calendar ( $\mathrm{J}=\mathrm{J}$ January, $\mathrm{F}=$ February, etc.). 
Geosci. Model Dev. Discuss., doi:10.5194/gmd-2016-168, 2016

Manuscript under review for journal Geosci. Model Dev.

Published: 29 September 2016

(c) Author(s) 2016. CC-BY 3.0 License.

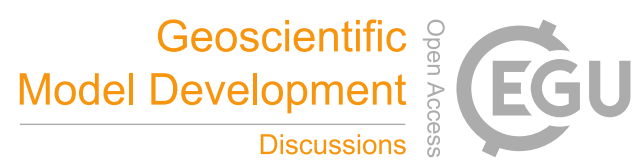

(c) (i)
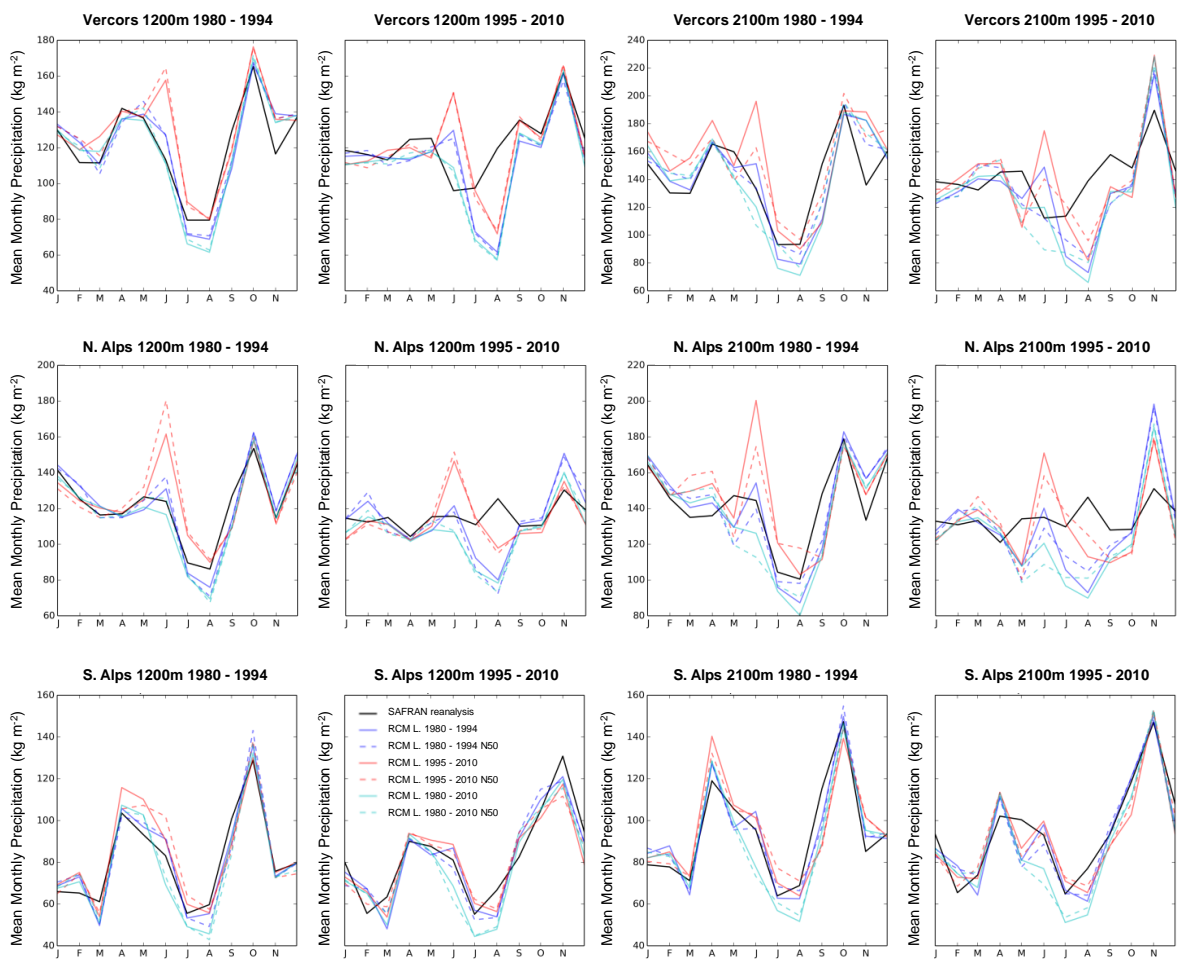

Figure 21. Mean annual cycle of precipitation in each adjusted RCM simulation and in SAFRAN over the period 1980-1994 and 1995-2010, for the Vercors massif, the Northern and Southern Alps, and at $1200 \mathrm{~m}$ a.s.l. and $2100 \mathrm{~m}$ a.s.l. Letters on the $\mathrm{x}$-axis correspond to the different months of the calendar $(\mathrm{J}=\mathrm{January}, \mathrm{F}=$ February, etc.). 
Geosci. Model Dev. Discuss., doi:10.5194/gmd-2016-168, 2016

Manuscript under review for journal Geosci. Model Dev.

Published: 29 September 2016

(c) Author(s) 2016. CC-BY 3.0 License.

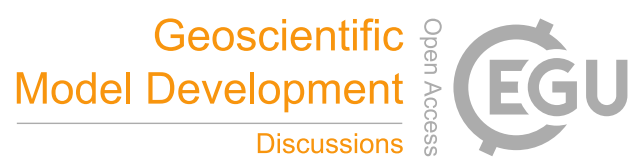

(c) (i)
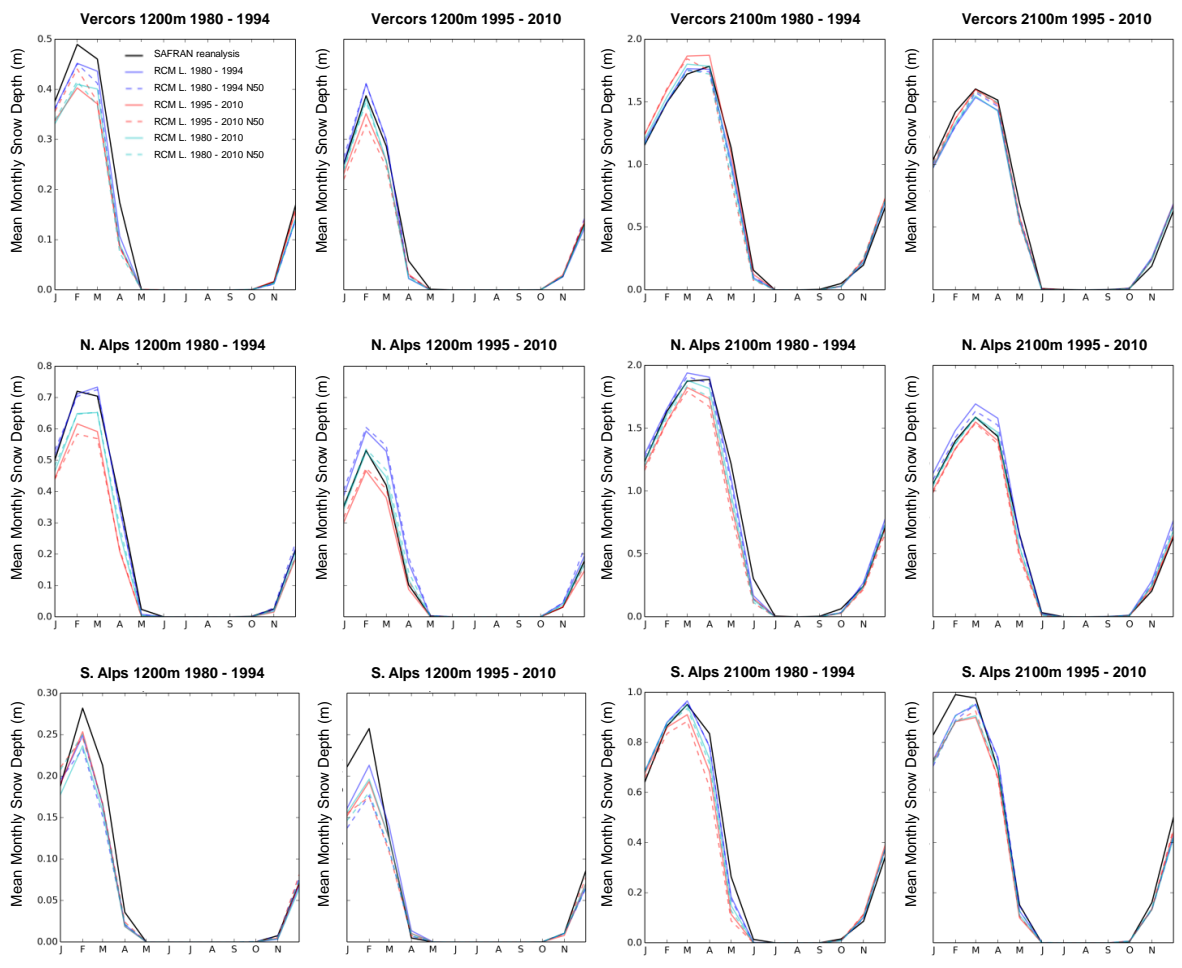

Figure 22. Mean annual cycle of snow depth in each adjusted RCM simulation and in SAFRAN over the period 1980-1994 and 1995-2010, for the Vercors massif, the Northern and Southern Alps, and at $1200 \mathrm{~m}$ a.s.l. and $2100 \mathrm{~m}$ a.s.l.. Letters on the $\mathrm{x}$-axis correspond to the different months of the calendar ( $\mathrm{J}=\mathrm{January}, \mathrm{F}=$ February, etc.). 
Geosci. Model Dev. Discuss., doi:10.5194/gmd-2016-168, 2016

Manuscript under review for journal Geosci. Model Dev.

Published: 29 September 2016

(c) Author(s) 2016. CC-BY 3.0 License.

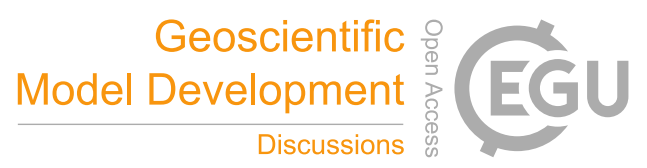

(c) (i)
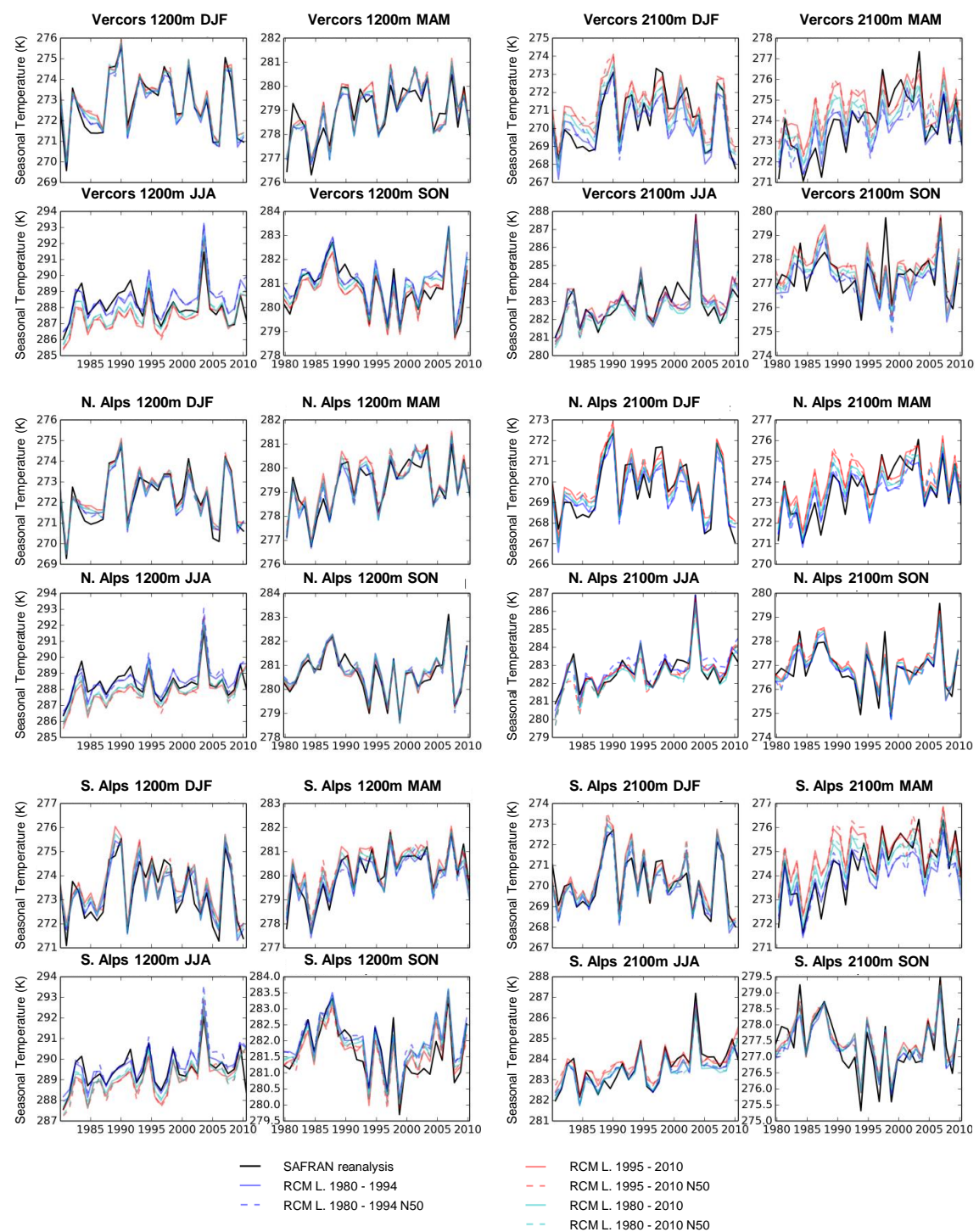

Figure 23. Seasonal average time series of temperature from 1979 to 2010 in each adjusted RCM simulation and in SAFRAN, for the Vercors massif, the Northern and Southern Alps, and at $1200 \mathrm{~m}$ a.s.l. and $2100 \mathrm{~m}$ a.s.1.. 
Geosci. Model Dev. Discuss., doi:10.5194/gmd-2016-168, 2016

Manuscript under review for journal Geosci. Model Dev.

Published: 29 September 2016

(c) Author(s) 2016. CC-BY 3.0 License.
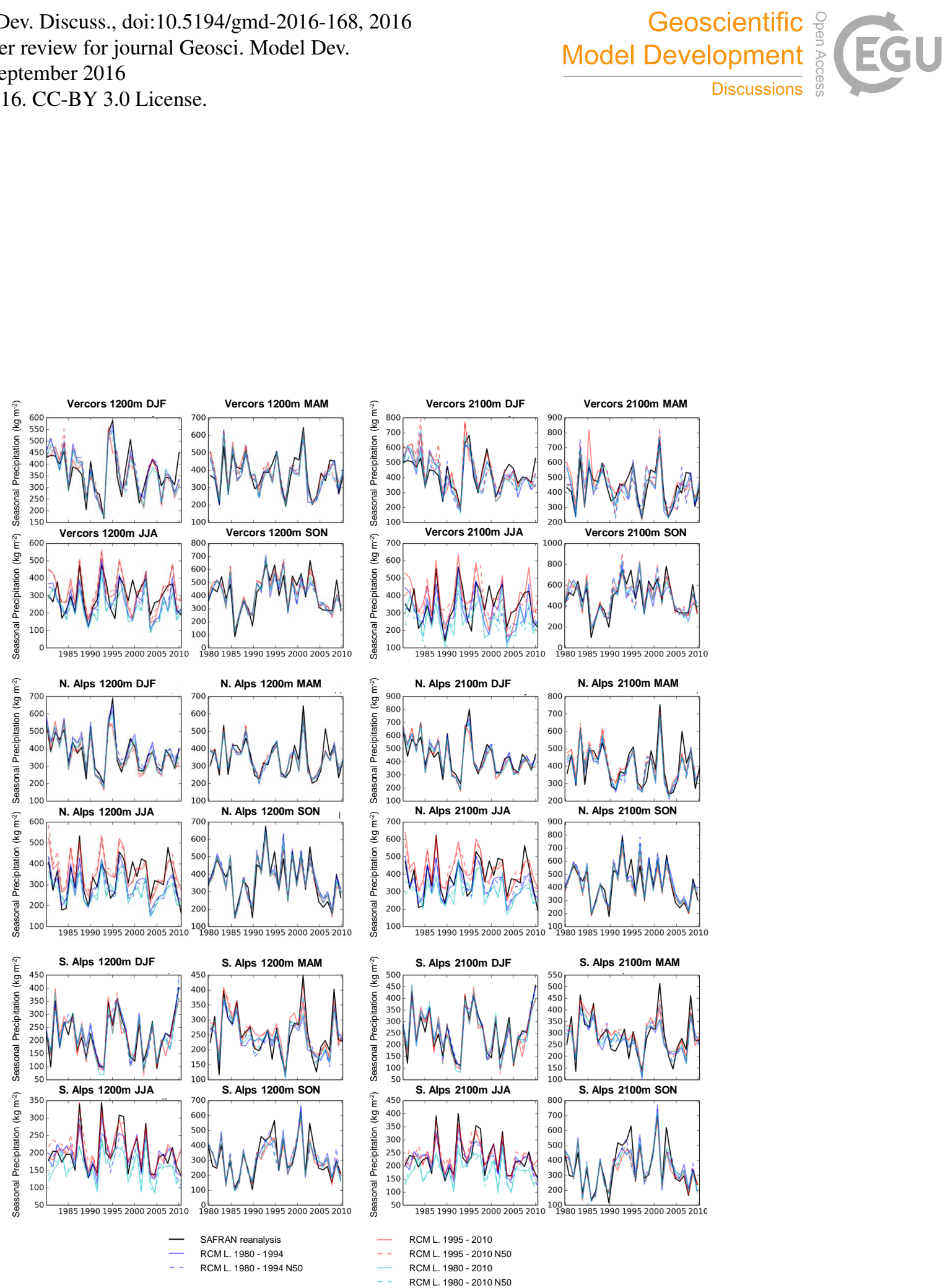

Figure 24. Seasonal average time series of precipitation from 1979 to 2010 in each adjusted RCM simulation and in SAFRAN, for the Vercors massif, the Northern and Southern Alps, and at $1200 \mathrm{~m}$ a.s.l. and $2100 \mathrm{~m}$ a.s.1.. 
Geosci. Model Dev. Discuss., doi:10.5194/gmd-2016-168, 2016

Manuscript under review for journal Geosci. Model Dev.

Published: 29 September 2016

(c) Author(s) 2016. CC-BY 3.0 License.
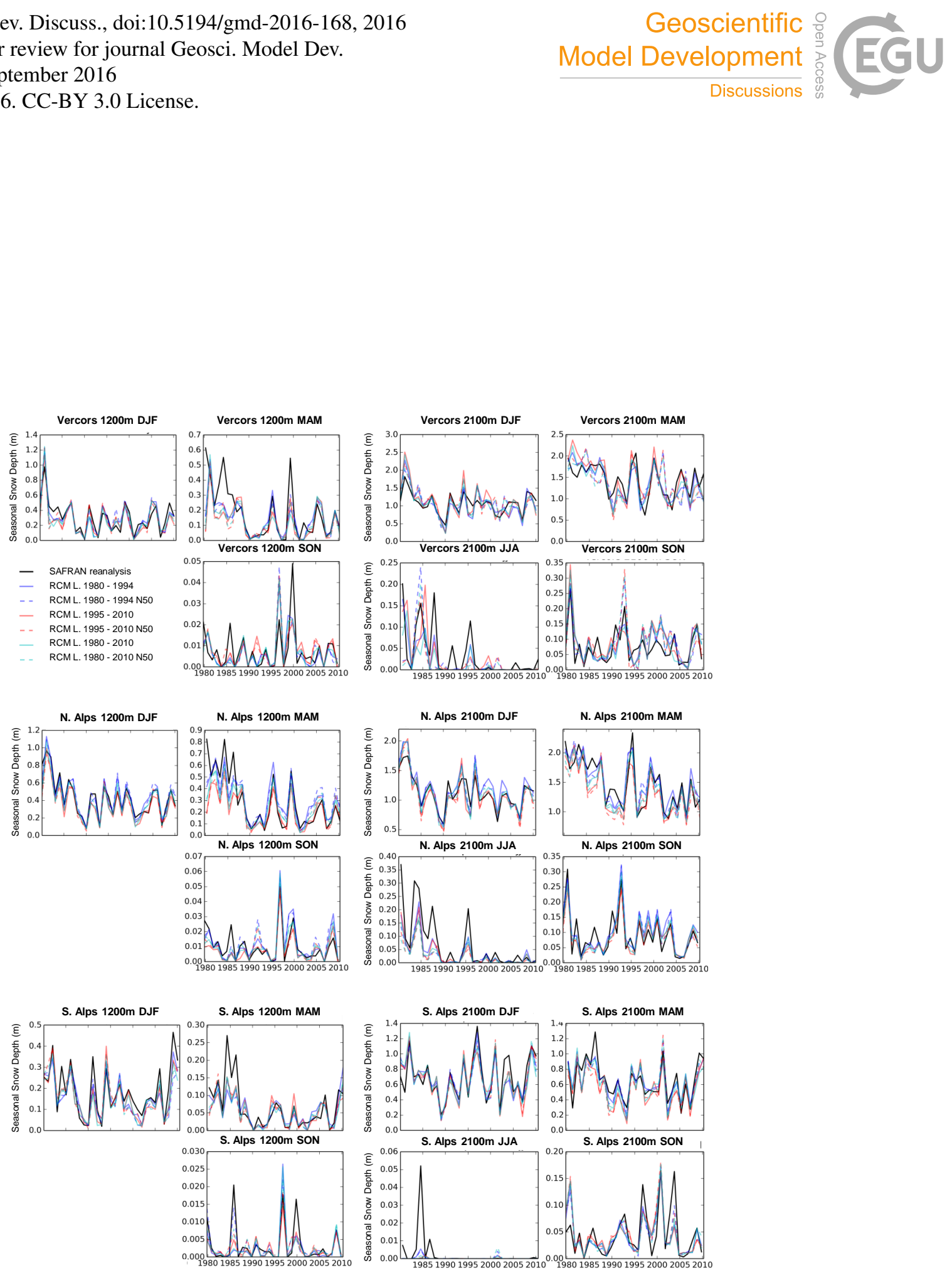

Figure 25. Seasonal average time series of snow depth from 1979 to 2010 in each adjusted RCM simulation and in SAFRAN, for the Vercors massif, the Northern and Southern Alps, and at $1200 \mathrm{~m}$ a.s.l. and $2100 \mathrm{~m}$ a.s.1.. 
Geosci. Model Dev. Discuss., doi:10.5194/gmd-2016-168, 2016

Manuscript under review for journal Geosci. Model Dev.

Published: 29 September 2016

(c) Author(s) 2016. CC-BY 3.0 License.

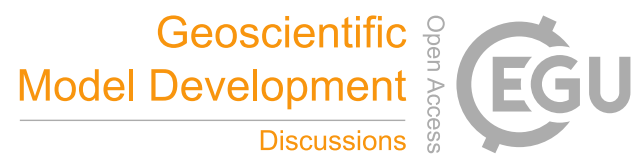

(c) (i)
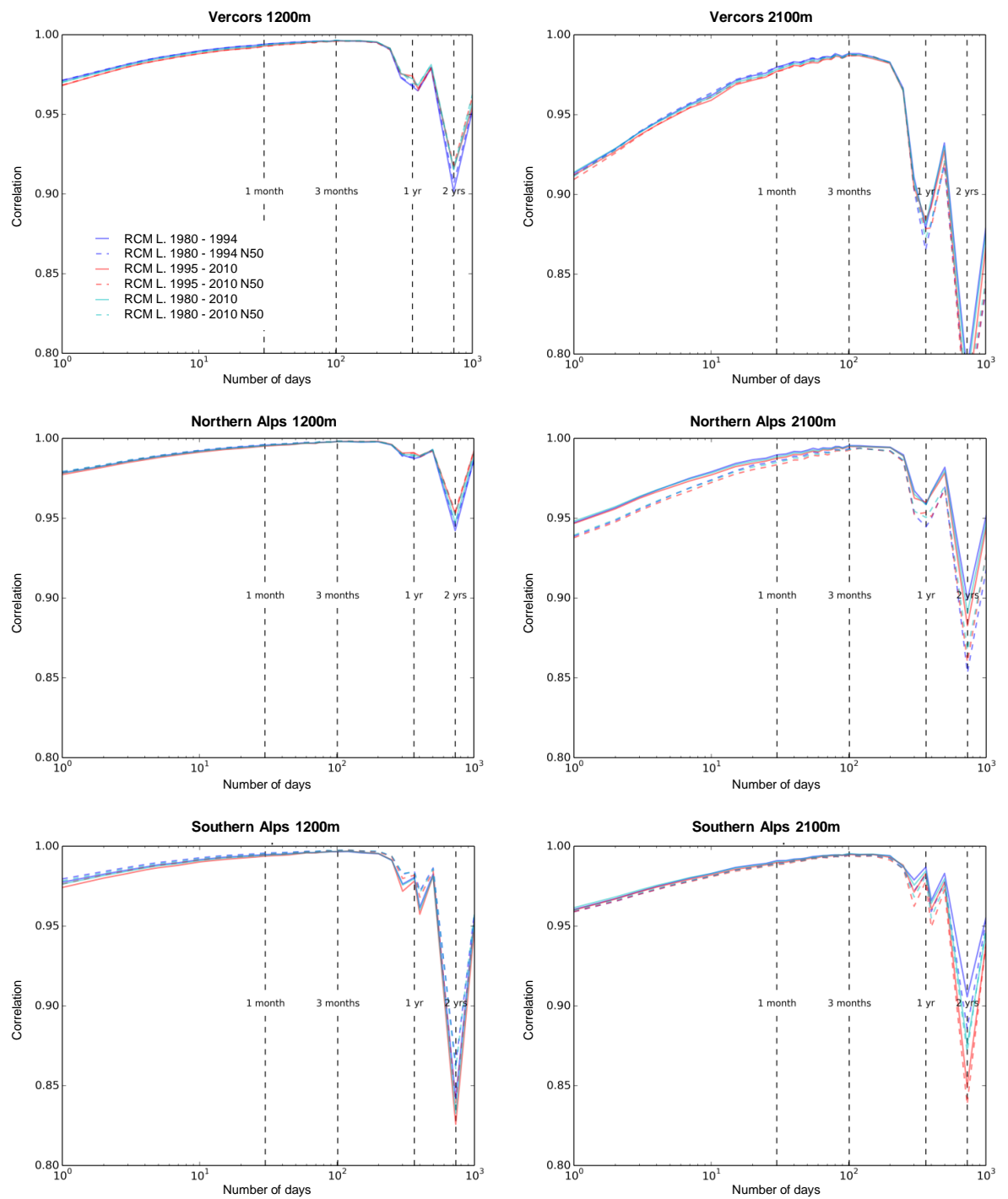

Figure 26. Correlation between SAFRAN and adjusted RCM temperature as a function of the integration time over the period 1979-2010, for the Vercors massif, the Northern and Southern Alps, and at $1200 \mathrm{~m}$ a.s.l. and $2100 \mathrm{~m}$ a.s.1.. 
Geosci. Model Dev. Discuss., doi:10.5194/gmd-2016-168, 2016

Manuscript under review for journal Geosci. Model Dev.

Published: 29 September 2016

(c) Author(s) 2016. CC-BY 3.0 License.

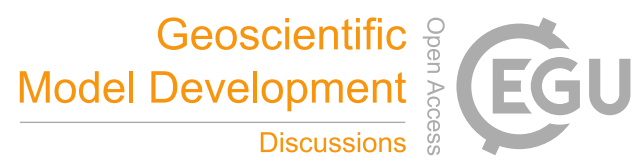

(c) (i)
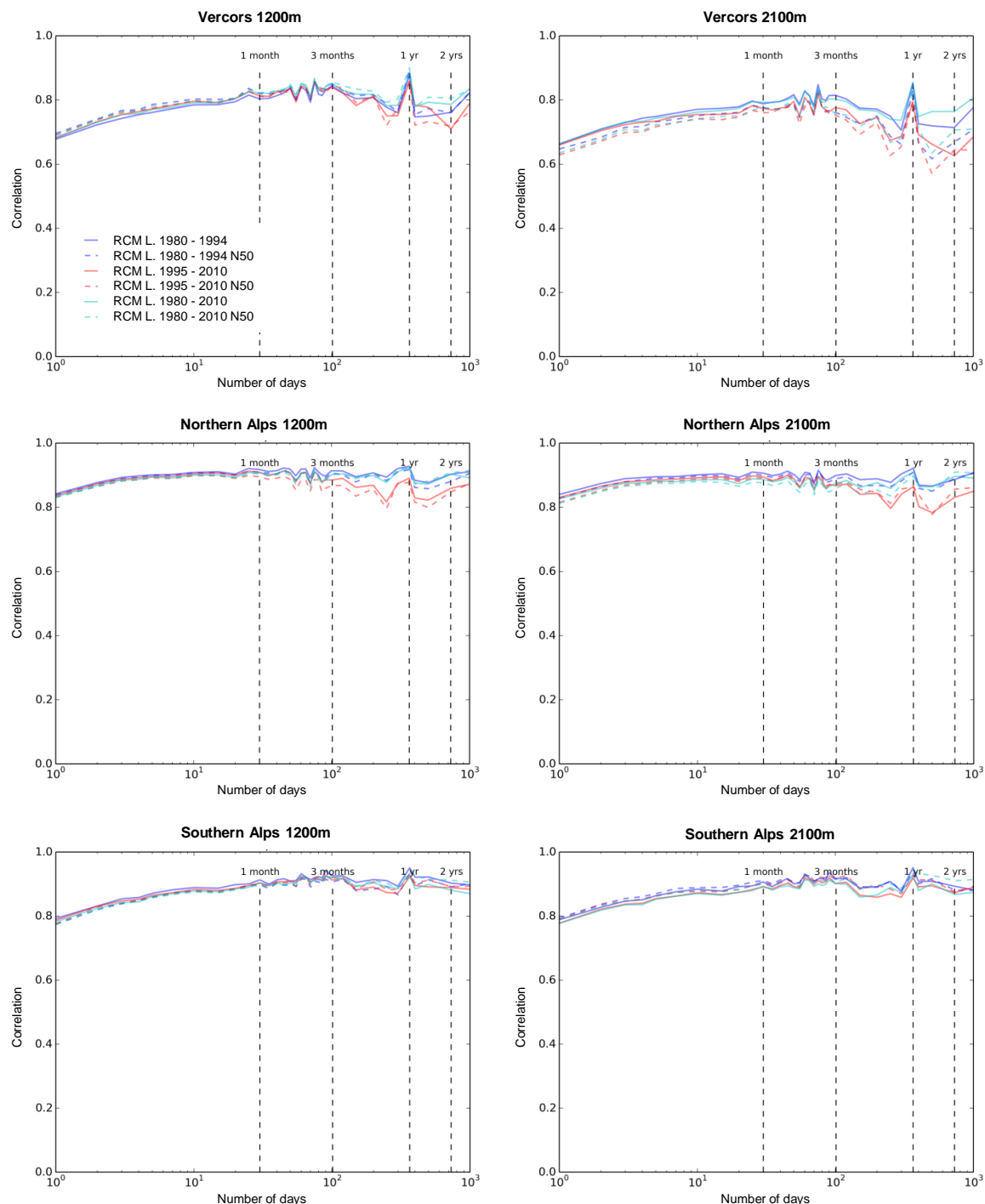

Figure 27. Correlation between SAFRAN and adjusted RCM precipitation as a function of the integration time over the period 1979-2010, for the Vercors massif, the Northern and Southern Alps, and at $1200 \mathrm{~m}$ a.s.l. and $2100 \mathrm{~m}$ a.s.l.. 
Geosci. Model Dev. Discuss., doi:10.5194/gmd-2016-168, 2016

Manuscript under review for journal Geosci. Model Dev.

Published: 29 September 2016

(c) Author(s) 2016. CC-BY 3.0 License.
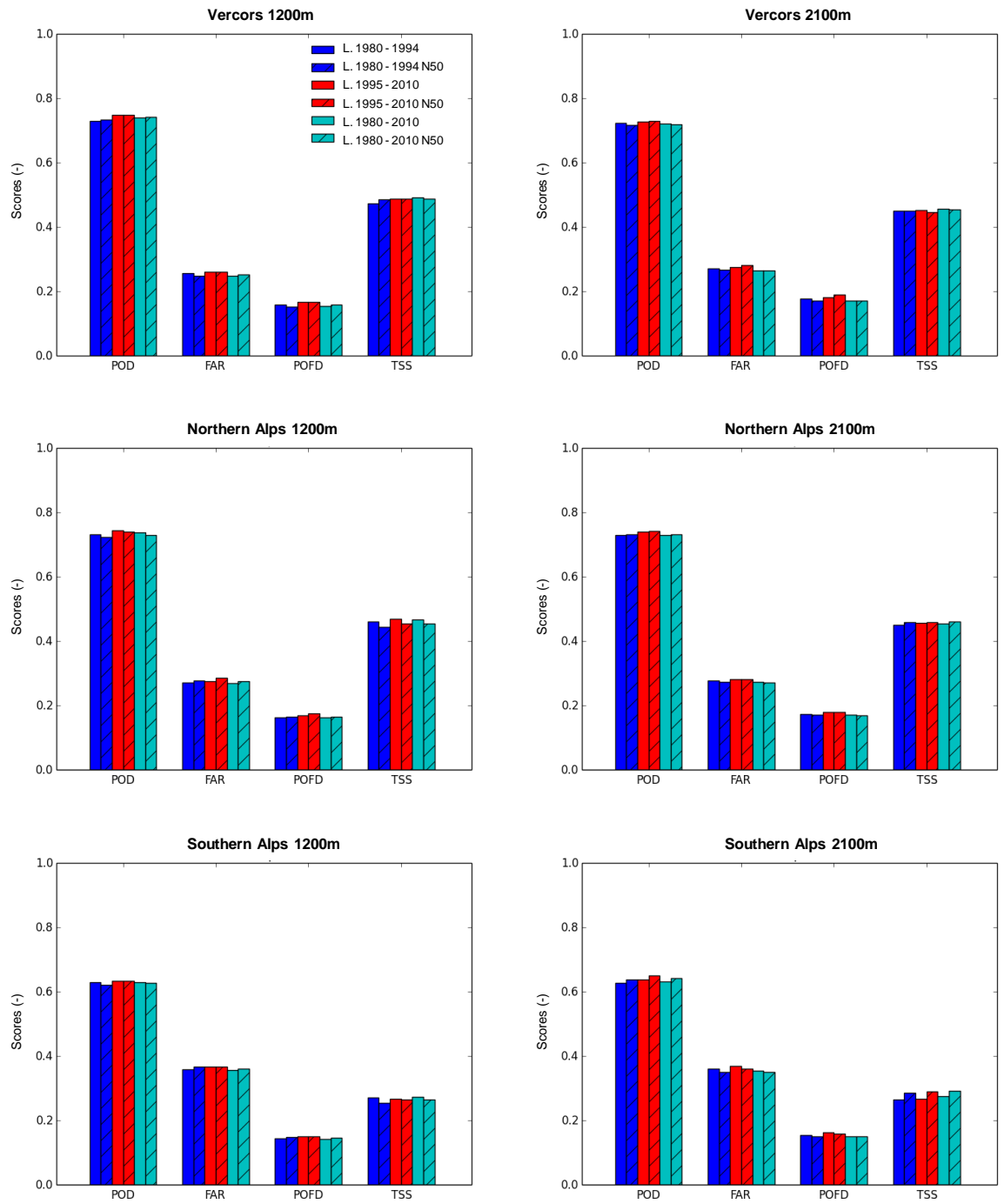

Figure 28. Scores for the detection of precipitation events in each adjusted RCM simulation compared to SAFRAN over 1979-2010, for the Vercors massif, the Northern and Southern Alps, and at $1200 \mathrm{~m}$ a.s.l. and $2100 \mathrm{~m}$ a.s.l. $\mathrm{POD}=$ probability of detection, $\mathrm{FAR}=$ false alarm rate, $\mathrm{POFD}=$ probability of false detection, TSS $=$ true skill score. 